\title{
Statin as a Potential Chemotherapeutic Agent: Current Updates as a Monotherapy, Combination Therapy, and Treatment for Anti-Cancer Drug Resistance
}

\author{
Nirmala Tilija Pun and Chul-Ho Jeong *(D) \\ College of Pharmacy, Keimyung University, 1095 Dalgubeol-daero, Daegu 42601, Korea; tilijanp@gmail.com \\ * Correspondence: chjeong75@kmu.ac.kr; Fax: +82-53-580-6645
}

check for

updates

Citation: Tilija Pun, N.; Jeong, C.-H.

Statin as a Potential

Chemotherapeutic Agent: Current

Updates as a Monotherapy,

Combination Therapy, and Treatment for Anti-Cancer Drug Resistance.

Pharmaceuticals 2021, 14, 470.

https://doi.org/10.3390/ph14050470

Academic Editors: Jacek Bil and

Monica Notarbartolo

Received: 12 March 2021

Accepted: 14 May 2021

Published: 16 May 2021

Publisher's Note: MDPI stays neutral with regard to jurisdictional claims in published maps and institutional affiliations.

Copyright: (c) 2021 by the authors. Licensee MDPI, Basel, Switzerland. This article is an open access article distributed under the terms and conditions of the Creative Commons Attribution (CC BY) license (https:/ / creativecommons.org/licenses/by/ $4.0 /)$.

\begin{abstract}
Cancer is incurable because progressive phenotypic and genotypic changes in cancer cells lead to resistance and recurrence. This indicates the need for the development of new drugs or alternative therapeutic strategies. The impediments associated with new drug discovery have necessitated drug repurposing (i.e., the use of old drugs for new therapeutic indications), which is an economical, safe, and efficacious approach as it is emerged from clinical drug development or may even be marketed with a well-established safety profile and optimal dosing. Statins are inhibitors of HMG-CoA reductase in cholesterol biosynthesis and are used in the treatment of hypercholesterolemia, atherosclerosis, and obesity. As cholesterol is linked to the initiation and progression of cancer, statins have been extensively used in cancer therapy with a concept of drug repurposing. Many studies including in vitro and in vivo have shown that statin has been used as monotherapy to inhibit cancer cell proliferation and induce apoptosis. Moreover, it has been used as a combination therapy to mediate synergistic action to overcome anti-cancer drug resistance as well. In this review, the recent explorations are done in vitro, in vivo, and clinical trials to address the action of statin either single or in combination with anti-cancer drugs to improve the chemotherapy of the cancers were discussed. Here, we discussed the emergence of statin as a lipid-lowering drug; its use to inhibit cancer cell proliferation and induction of apoptosis as a monotherapy; and its use in combination with anti-cancer drugs for its synergistic action to overcome anti-cancer drug resistance. Furthermore, we discuss the clinical trials of statins and the current possibilities and limitations of preclinical and clinical investigations.
\end{abstract}

Keywords: statin; drug repurposing; anti-cancer; apoptosis; resistance

\section{Background}

Cancer, a chronic disease, is a leading cause of death worldwide [1,2] and seriously threatens human health [3,4]. Different technologies such as surgery, radiotherapy, chemotherapy, targeted therapy, radiopharmaceutical therapy, gene therapy, and cancer immunotherapy have been developed as modes of treatment, and most of them reach clinical trials [5-8]. Despite the tremendous research and resources being investigated to prevent and cure cancers, they remain incurable owing to metastasis, recurrence, and resistance [9]. Therefore, it remains necessary to develop additional technologies or drugs to reduce the rate of cancer-caused deaths. However, the successful translation of new drugs and technologies from the development phase to clinical practice requires an average of 13 years of research with an investment of USD \$1.8 billion [10,11]. This is because preclinical and clinical studies are a key step in testing the safety and efficacy of a new drug in humans [12] for use. After the discovery of a new drug, it undergoes preclinical testing, including evaluation in vitro (cell culture) and in vivo (animal) models for determining the preliminary safety, efficacy, and pharmacokinetics of a drug. When its preclinical study is approved, it further undergoes clinical trials in human subjects; these trials comprise phase I (a small group of people, 20-100), II (a larger number of people, 20-300), III (a large group 
of patients, 300-3000), and IV (the largest group of patients, >3000). Altogether, clinical trials include testing a drug for its safety, tolerability, pharmacokinetics, and pharmacodynamics. Following a phase III clinical trial, a drug can be approved in the United States by the Food and Drug Administration (FDA) or in the European Union by the European Medicines Agency (EMEA). Phase IV studies occur after the approval of a drug and are marketed for use over a longer period while still being monitored [10,12,13]. However, most drugs fail in their phase II clinical trial [14], and only $8 \%$ of new molecular entities (NMEs) successfully progress from the pre-clinical stage to the final launch [10].

Consequently, the concept of drug repurposing (in other words "new indications of old drug") evolved to enable shortening of the development cycle and saving resources in drug discovery and development, along with a reduction in the risk of failure in early clinical trials. This concept involves utilization of an existing clinically approved drug for a novel indication so that a new mode of action can be applied for that condition [15]. On the basis of this concept, several researchers and clinicians are focusing on drugs approved for use in cancer to fulfill the need for new cancer therapies [16-18]. The advantage of this approach is that the documentation of the pharmaceutical agent is available with a history of clinical use (pharmacokinetics, bioavailability, toxicity, protocol, and dosing) established in phase I clinical studies. Therefore, these drugs could be rapidly advanced into phase II and phase III, and the associated cost and time could be significantly reduced [19].

Drug repurposing approaches are achieved either experimentally or through a computational method by identification of drugs with new indications, new targets, new effects, and unexplored mechanisms [20]. It has received increasing attention not only from the pharmaceutical industry but also from the public sector and academia, as it is a faster and cheaper strategy for enlarging the collection of approved drugs. Furthermore, it has gained acceptance with respect to cancer treatment as cancer is difficult to cure, and it takes a long time for a new drug to be discovered and implemented. Different drugs available in the market have been repurposed in cancer therapy, such as cardiovascular drugs, antipsychotic and antidepressant drugs, microbiological agents, antiviral drugs, antibiotics, nonsteroidal anti-inflammatory drugs (NSAIDs), aspirin, metformin, selective estrogen receptor modulators (SERMS), and statins [21].

Cancer resistance, which is characterized by tumor relapse or spread, remains a major challenge in clinical oncology; its occurrence is attributed to unsuccessful adaptation and evaluation of the treatment modality [3,5]. Chemotherapeutic resistance is mediated by two mechanisms: intrinsic and acquired resistance. Intrinsic resistance occurs before treatment because of resistance-mediating factors that exist in the bulk of tumors, which later renders cancer therapy inefficient. In contrast, acquired resistance develops during or after treatment of tumors that are sensitive initially but can develop mutations later or after adaptive responses such as mutation, drug efflux, drug activation/inactivation, and alteration of the drug target $[4,22]$. Several drugs such as immunomodulatory drugs, antihypertensives (calcium channel blockers, angiotensin II receptor inhibitors, diuretics, and $\beta$-blockers), antidiabetics (biguanides and thiazolidinediones), anthelmintics (niclosamide, mebendazole, albendazole, and ivermectin), antimalarials (chloroquine and hydroxychloroquine; primaquine; and mefloquine, amodiaquine, and artemisinin derivatives), anti-fungals (itraconazole), antibiotics (anisomycin, monesin, salinomycin, gramicidin A, and minocycline), and antivirals (brivudine and phenothiazines) have been considered potentially to be repurposed to resensitize multi-drug resistant cancers to conventional chemotherapeutic agents [23]. Therefore, the concept of drug repurposing is a potential strategy in overcoming chemotherapeutic resistance.

In this review, we discuss the possibility of repurposing statins for various cancers. We particularly focus on different possible approaches for using statins, such as an anticancer monotherapy in combination with other chemotherapeutic drugs for achieving a synergistic effect, as well as in combination with other chemotherapeutic drugs for overcoming resistance. Additionally, we discuss the effect of statins on resistance development 
and tolerance, highlight relevant signaling pathways associated with statins, and briefly describe clinical studies on repurposing statins.

\section{The Emergence of Statin as a Lipid-Lowering Drug}

Cholesterol is essential for the functioning of all organs in humans; however, an elevated cholesterol level is a risk factor for atherosclerosis and coronary heart disease. 3-Hydroxy-3-methyl-glutaryl-CoA (HMG-CoA) reductase is the rate-limiting enzyme in the cholesterol biosynthesis pathway [24]. Therefore, the inhibition of HMG-CoA reductase is needed for reducing cholesterol synthesis in the treatment of atherosclerosis and coronary heart disease, which were the leading causes of death in 1950. In 1950 and 1960, several companies and researchers explored molecules that could block a step of cholesterol synthesis, which is comprised of 30 steps; consequently, compactin/mevastatin was discovered in 1967 as the first statin that strongly inhibited HMG-CoA reductase to lower serum cholesterol levels $[25,26]$. However, owing to the development of serious side effects such as flushing, gastrointestinal (GI) discomfort, gallstone, liver disease, and cataract, it was removed from the market [26]. In 1979, two research groups, Merck Research Laboratory and Tokyo University of Agriculture and Technology, isolated statins named mevinolin and monocolin $\mathrm{K}$ from Aspergillus terreus and Monasus ruber, respectively. However, as mevinolin and monocolin $\mathrm{K}$ were determined to be the same compound, it was named lovastatin, which later became the first commercial statin in September 1987 [24-26].

Due to the issue of optimal clinical activity of lovastatin and the lack of patent protection in many countries, the efficacy of lovastatin led to the discovery of simvastatin, which is more potent than lovastatin [27]. As is the case for all discovered statins, compactin, lovastatin, and simvastatin are closed ring structures, meaning they are inactive prodrugs that need reopening for the activity. This has led to the discovery of open ring structure statins, i.e., pravastatin, fluvastatin, atorvastatin, rosuvastatin, and pitavastatin (Figure 1) [27,28]. In 1989, atorvastatin was discovered as the first synthetic statin with a potent novel hypolipidemic effect; it was marketed in the United States as LIPITOR [29]. Later, it was recommended as the first-line therapy for patients with low to high risk of coronary heart disease, as it reduces the risk of cardiovascular morbidity and mortality [30].

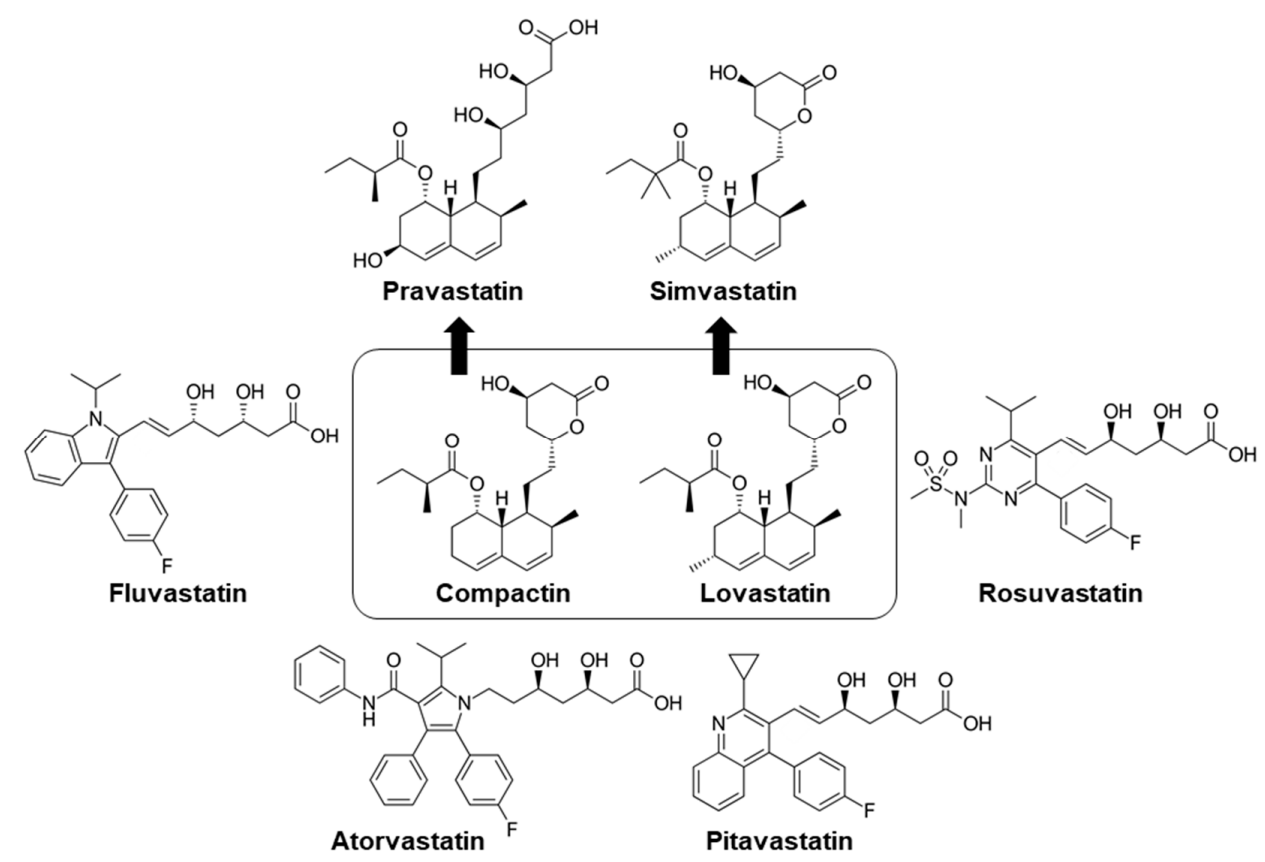

Figure 1. Chemical structure of all major statins (derived from [25]). 
The use of statin is not beyond side effects. After the use of statin, the patient suffers from liver toxicity although the incidence of this is low. Moreover, statin has increased the incidence of diabetes risk by 20-30\%. Myopathy is also another frequent toxicity encountered in daily practice, although the nature of muscle pain is unclear. Other potential toxicities such as proteinuria and hematuria have been described as well (Table 1) [27].

\section{Statin Repurposed in Cancer Therapy}

Being overweight or obese is linked to the development and recurrence of breast cancer [31]. Tumor cells show high avidity for cholesterol, as well as an accumulation of intracellular cholesterol supports proliferation, growth, and metastasis of cancers $[32,33]$. Furthermore, the inhibition of the mevalonate pathway, a metabolic pathway of cholesterol synthesis, or lowering of cholesterol, has been proven to prevent cancer progression $[34,35]$. Statin, a drug that inhibits the rate-limiting step of the mevalonate pathway, particularly the HMG-CoA reductase enzyme, has gained interest for its use in overcoming mycobacterial infection, insulin, and cancer resistance [36-38]. In addition, the inhibition of the cholesterol biosynthetic pathway has shown a promising effect in reducing the formation of mammospheres enriched with cancer stem cells, indicating that the cholesterol biosynthetic pathway is a potential therapeutic target for statin treatment in breast cancers [39].

Other statins such as simvastatin, atorvastatin, and rosuvastatin suppress geranylgeranylation and expression of transforming growth factors (TGF- $\beta 1$ ); vascular endothelial growth factor (VEGF); and the tumor-promoting cytokines and mediators IL-6, IL-8, and TNF- $\alpha$, inhibiting ovarian cancer cell growth [40]. Statins have been used as a single agent to decrease cell proliferation and to induce apoptosis in many cancer cells. Moreover, they have been used in combination with other chemotherapeutic drugs for improving the efficacy of drugs and the condition of the patient. For example, clinical data shows that the concomitant use of statins and trastuzumab lowers the cardiotoxicity of trastuzumab-based therapy in HER2-positive breast cancers [41]. Inhibition of the mevalonate pathway using statins (pitavastatin, simvastatin, lovastatin, atorvastatin, pravastatin, and rosuvastatin) inhibits radiation resistance in head and neck cancers, indicating that the mevalonate pathway can serve as a vital target for overcoming resistance development [42]. Moreover, statins in combination with metformin have been shown to decrease the all-cause mortality of prostate cancer patients at high risk, particularly in post-diagnostic settings [43].

Table 1. Clinical trials showing the use of statins with their clinical indications, toxicities, doses, and human plasma concentration.

\begin{tabular}{|c|c|c|c|c|c|c|}
\hline S.N. & Statin & Clinical Indication & Doses & $\begin{array}{c}\text { Human Plasma } \\
\text { Concentration }\end{array}$ & Toxicity & Ref \\
\hline 1 & Lovastatin & Multiple myeloma & $\begin{array}{c}2 \mathrm{mg} / \mathrm{kg} \text { days } \\
1-5,8-12 \text { and } \\
0.5 \mathrm{mg} / \mathrm{kg} \text { days } \\
15-28 \text { of } \\
\text { each cycle }\end{array}$ & - & $\begin{array}{l}\text { Somnolence, fatigue and } \\
\text { constipation, deep vein } \\
\text { thrombosis, pulmonary } \\
\text { embolism }\end{array}$ & {$[44,45]$} \\
\hline 2 & Simvastatin & $\begin{array}{l}\text { Refractory multiple } \\
\text { myeloma, pancreatic cancer, } \\
\text { colorectal cancer, }\end{array}$ & $\begin{array}{c}30 \mathrm{mg}, \\
80 \mathrm{mg} \text { daily }\end{array}$ & - & $\begin{array}{l}\text { Hematoxicity, bone pain, } \\
\text { gastrointestinal side effects, } \\
\text { infections, muscle pain, } \\
\text { fatigue, anemia, depression }\end{array}$ & [46-48] \\
\hline 3 & Pravastatin & $\begin{array}{c}\text { Gastric cancer, } \\
\text { hepatocellular carcinoma } \\
(\mathrm{HCC})\end{array}$ & $20-40 \mathrm{mg} / \mathrm{kg}$ & - & Diarrhea, stomatitis & {$[49]$} \\
\hline 4 & Fluvastaatin & Prostate cancer & $80 \mathrm{mg}$ & $\begin{array}{c}63.4 \mathrm{ng} / \mathrm{mL} \text { or } \\
0.2 \mu \mathrm{M} \\
(0.0-437.0 \mathrm{ng} / \mathrm{mL} \\
\text { or } 0.0-1.1 \mu \mathrm{M})\end{array}$ & - & {$[50]$} \\
\hline 5 & Atorvastatin & Prostate cancer & $80 \mathrm{mg}$ & $3.6 \mathrm{ng} / \mathrm{mL}$ & - & [51] \\
\hline 6 & Rosuvastatin & $\begin{array}{l}\text { Advanced solid } \\
\text { malignancies }\end{array}$ & $\begin{array}{c}20 \text { mg, } \\
80 \text { mg daily }\end{array}$ & - & $\begin{array}{l}\text { Fatigue, myalgia, } \\
\text { muscle weakness }\end{array}$ & {$[52,53]$} \\
\hline
\end{tabular}




\section{Statin as a Single Agent in the Suppression of Cancer Cell Proliferation, and the Induction of Apoptosis}

Statin was studied in vitro for its anti-proliferative and apoptotic effect in cancer cells such as medulloblastoma brain tumor, colorectal cancer, lung cancer, oral squamous cell carcinoma, anaplastic thyroid cancer, and hepatic cancer (Figure 2) [54-60]. Lovastatin augments sensitivity by activating bone morphogenetic protein (BMP), a tumor-suppressive protein, and reducing cancer stemness in colorectal cancer cells [61]. The anti-cancer effect of statin is also mediated by inhibiting the activity of DNA methyltransferases (DNMTs) $[60,61]$, leading to demethylation and activation of BMP signaling, which causes a shift in the stem-like state to a differentiated form of cancer cells [61] and induction of p21 cip, causing cell-cycle arrest [60]. In contrast, it inhibits breast cancer cell proliferation via induction of cell-cycle arrest and apoptosis [62,63]. Simvastatin has been shown to modulate intrinsic and extrinsic apoptosis simultaneously in prostate cancer cells. It enhances phosphorylated Bad, and cleavage of caspases $9 / 3$ but reduces Bcl-2 and Bcl-xL as intrinsic apoptotic markers. While as extrinsic apoptosis, it increases TNF, Fas-L, Traf, and caspase 8 cleavage [64]. It also induces cholangiocarcinoma cancer cell death by disrupting the colocalization of Rac1/lipid rafts, depressing Rac1 activity, and suppressing the expression of ATP-binding cassettes (ABCA1 and ABCG1) $[65,66]$. The anti-cancer effect of simvastatin in salivary adenoid cystic carcinoma (SACC) is further enhanced by the inhibition of microRNA-21, as it is highly expressed in tumors and promotes tumor development [67]. A clinical study conducted in Taiwan National Health Insurance Research Database (NHIRD) in a cohort of 15,264 hyperlipidemic prostate cancer patients shows that the mortality rate was decreased in patients receiving simvastatin or lovastatin [68]. Additionally, simvastatin improves the radiosensitivity of esophageal cancers by inducing the tumor suppressor protein PTEN and inhibiting the tumor-promoting signaling PI3K/Akt pathway, leading to a decrease in proliferation, invasion, migration, and induction of apoptosis [69].

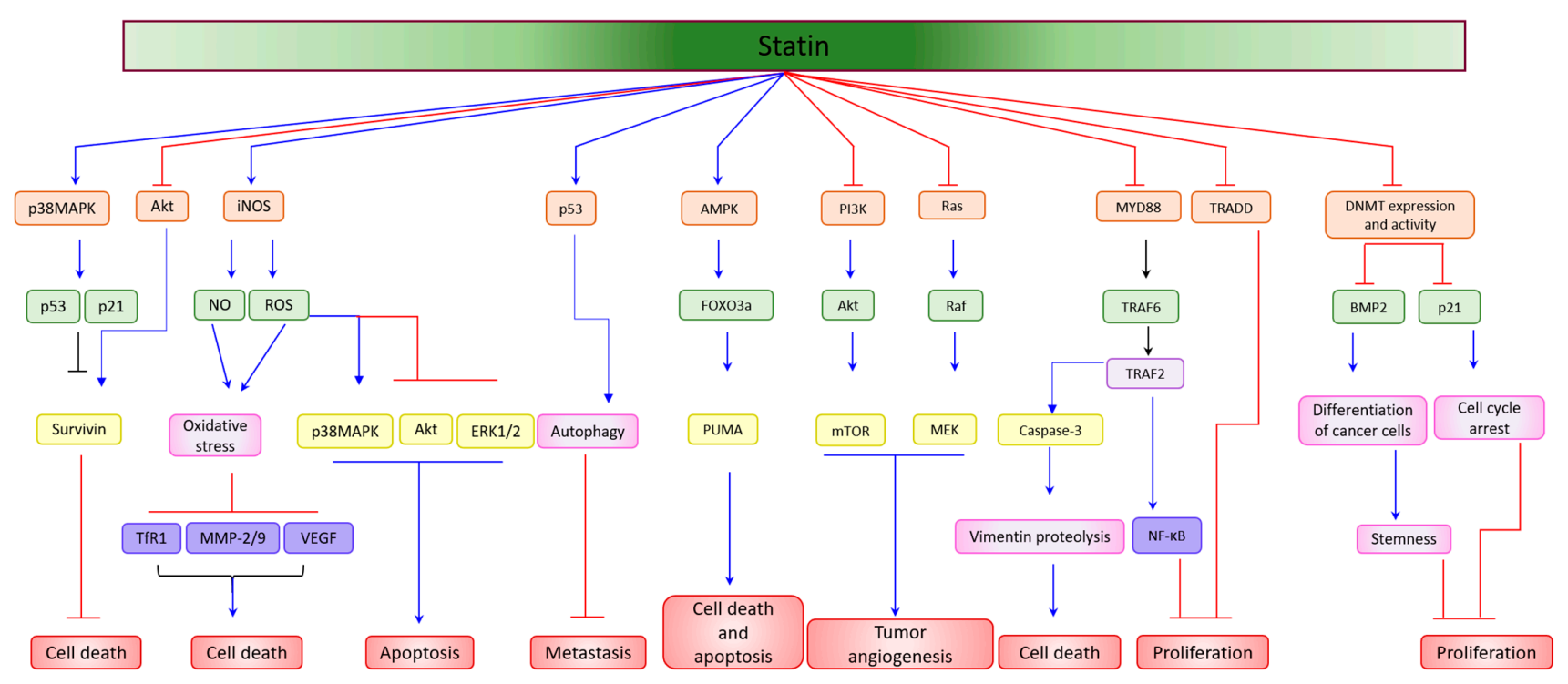

Figure 2. Statins alone as anti-cancer agents. Statin as a monotherapy upregulates or inhibits diverse signaling cascades leading to induction of oxidative stress, cell-cycle arrest, differentiation of cancer cells, autophagy, and suppression of cancer stemness, proliferation, metastasis, angiogenesis. As a result, statin induces cell death, cytotoxicity, and apoptosis of cancer cells. Blue arrows indicate upregulation, red colored lines indicate inhibition/suppression.

Pravastatin suppresses the viability of multiple myeloma cells by decreasing the production of growth factors such as VEGF and bFGF, and inducing cell-cycle arrest [70]. Furthermore, it hinders the proliferation and invasion of human HCC cells [71]. It is an effective anti-fibrotic agent that reverses radiation-induced fibrosis of head and neck cancers [72]. Fluvastatin hinders the glycosylation of FLT3 in human and murine cells, 
acting as an anti-cancer agent and prolonging the survival of FLT3/ITD leukemic mouse models [73]. Fluvastatin inhibits cancer cell proliferation and induces apoptosis in cancer cells such as breast cancer, cervical cancer, glioma, and lymphoma [74-79]. Fluvastatin, cerivastatin, and pitavastatin have demonstrated potent anti-proliferative effects along with the induction of autophagy in primary glioblastoma cell lines [80]. In a nude mouse model, fluvastatin prevented lung adenocarcinoma bone metastasis, which is largely dependent on p53-mediated autophagy induction [81]. Fluvastatin conjugated with human immunodeficiency virus type 1 (HIV-1) trans-activator transcription peptide (TAT) produces anti-proliferative action against human hepatoma cancer cells through a concomitant accumulation of cells in the pre-G phase and induction of caspase 3 cleavage [82]. Atorvastatin causes strong growth inhibition of epithelial- and mixed epithelial-mesenchymal cancer cells by inhibiting the protein prenylation pathway [83]. Rosuvastatin inhibits cell proliferation and spheroid formation without cytotoxicity in prostate cancer cells and inhibits the expression of EMT markers vimentin, and Zeb-1 [84]. Novel small molecules based on isocoumarins/3-alkylidenephthalides that were derived from rosuvastatin have shown promising properties for use as anti-cancer drugs in the future [85]. Furthermore, gel-loaded rosuvastatin [86], fabrication of rosuvastatin [87], and biocompatible copolymeric micelles of rosuvastatin [88] have shown an anti-cancer effect in aggressive tongue carcinoma, hepatic cancer, and breast cancer, respectively, with improved efficacy compared to rosuvastatin alone. Pitavastatin treatment induces cell death in ovarian cancer cells in which hydroxymethylglutarate coenzyme-A reductase (HMGCR) is upregulated and TP53 is mutated, and the anti-cancer effect of pitavastatin is solely mediated by the inhibition of HMGCR [89]. Pitavastatin further inhibits AKT activation while activating AMPK, which leads to FOXO3A activation and induction of PUMA, ultimately inducing apoptosis in oral squamous cancer [90]. Pitavastatin overcomes radiotherapy resistance in breast cancer and melanoma models by increasing DNA double-strand breaks [91]. Cerivastatin inhibits proliferation, migration, invasion, metastasis, and angiogenesis in several cancers such as aggressive breast cancers and glioblastoma [92-96].

\section{Statins Possess Synergistic Action to Overcome the Resistance to Anti-cancer Therapies}

We next discuss the in vitro synergistic effects of statins with other anti-cancer drugs (Figure 3) and their potential for overcoming drug resistance to different chemotherapeutic drugs (Figure 4). These are summarized in Table 2.

\subsection{Doxorubicin}

Doxorubicin (DOX), isolated from Streptomyces spp., is a topoisomerase II inhibitor belonging to the family of anthracycline anticancer drugs that breaks the DNA chain for replication, stopping the process of replication [97]. It is used for the treatment of wide range of cancers. However, the resistance among cancer cells has emerged as a major barrier to effective treatment using DOX. Simvastatin induces glutathione (GSH)-mediated suppression of ABCG4 (which causes efflux of intracellular doxorubicin and cisplatin) levels, increasing the sensitivity of prostate cancer cells to doxorubicin or cisplatin and leading to the suppression of tumor growth and size without doxorubicin-induced cytotoxicity [98]. An in vivo tumor xenograft model of breast cancer showed that encapsulation of fluvastatin in a hyaluronan-conjugated liposome and administration with doxorubicin produced a potent anti-proliferative effect with the longest survival in mice [99]. Atorvastatin sensitizes the anti-cancer effect of doxorubicin and cisplatin in human osteosarcoma by suppressing matrix metalloprotease 2 (MMP2) induced by doxorubicin and cisplatin [100]. Cerivastatin enhances the anti-tumor activity of doxorubicin and cisplatin against human breast cancer cells [101]. 


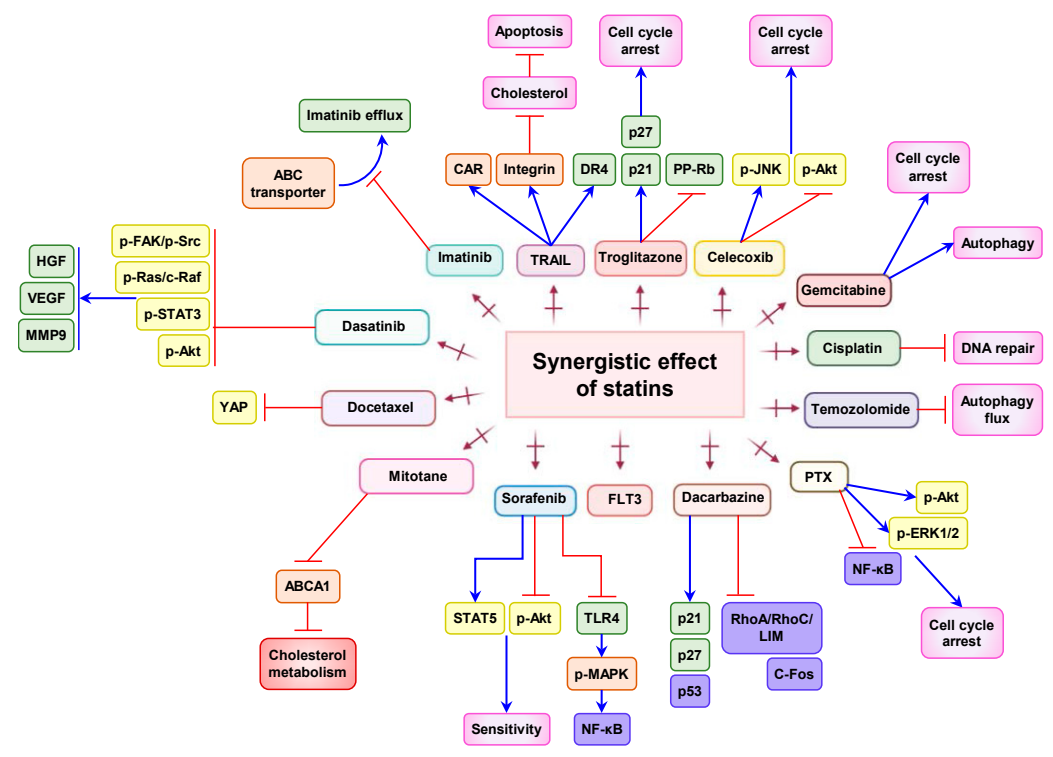

Figure 3. Synergistic action of statins. Statin in combination with anti-cancer drugs such as imatinib, TRAIL, troglitazone, celecoxib, gemcitabine, cisplatin, temozolomide, PTX, dacarbazine, FLT3, sorafenib, mitotane, docetaxel, and dasatinib synergistically suppress and induce signaling cascade leading to cell-cycle arrest, cell death, apoptosis, and sensitivity. Blue arrows indicate upregulation, black colored lines indicate inhibition/suppression, and red arrows indicate the combination of statin with indicated drugs.

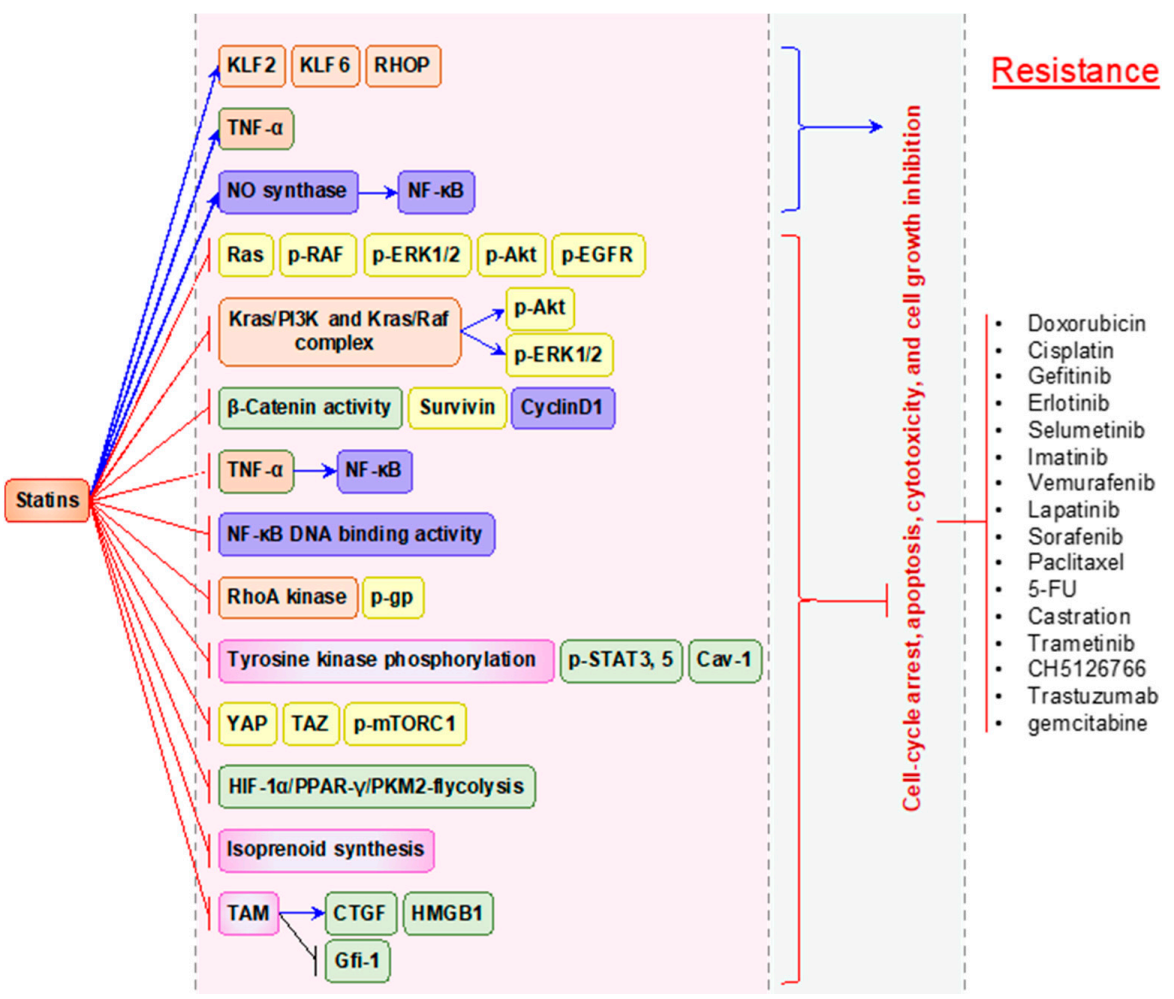

Figure 4. Statins for overcoming anti-cancer drug resistance. Statin overcomes the resistance developed by various anti-cancer drugs (as indicated in the figure) through the induction of cell-cycle arrest, apoptosis, cytotoxicity, and inhibition of cell growth. In most cases, statin inhibits the signaling molecules or kinases involved in cancer cell proliferation, growth, metastasis, angiogenesis, inflammation, and multi-drug resistance mechanism developed by those anti-cancer drugs. Blue arrows indicate upregulation, red colored lines indicate inhibition/suppression. 
Among statins, simvastatin has been well studied in the context of overcoming chemotherapeutic resistance. An initial study was performed in doxorubicin, in which simvastatin and mevastatin treatment effectively improved doxorubicin resistance in human malignant mesothelioma (HMM). As the development of doxorubicin resistance is caused by the efflux of it by drug efflux mechanism, decrease in doxorubicin resistance is mediated by the inactivation of the $\mathrm{ABC}$ transporter P-glycoprotein (P-gp) by nitric oxide (NO)-dependent nitration of a tyrosine residue of P-gp [102]. Further, the combination of simvastatin with phenothiazine derivatives improves resistance to doxorubicin in colon cancer cells by suppressing the mRNA and protein expression of multi-drug resistance protein, P-gp, and inflammation markers Cox-2 [103]. Similarly, simvastatin has been observed to decrease multidrug resistance (MDR1) protein and P-gp in leukemic cells, and a decrease in its expression is an additional mechanism underlying the simvastatin-mediated increase in chemosensitivity and overcoming of drug resistance [104]. Doxorubicin mediates resistance in chronic lymphocytic leukemia (CLL) by upregulating RhoA/RhoA kinase, Ras/ERK1-2, Akt, HIF-1 $\alpha$, and P-gp activities; simvastatin inhibits this effect, overcoming doxorubicin resistance [105]. Doxorubicin has been observed to develop resistance in urothelial bladder cancer by inducing the mevalonate (cholesterol) biosynthetic pathway; simvastatin inhibits the mevalonate pathway, thus reversing doxorubicin resistance [106]. Furthermore, simvastatin overcomes doxorubicin-mediated resistance of colon cancer cells by potentiating the anti-cancer activity of oxicam derivatives, leading to apoptosis induction and suppression of cell survival [107]. In addition, simvastatin and mevastatin in combination with flavonoids inhibited doxorubicin resistance in colon cancer cells [108]. Different statins have shown different behaviors in terms of overcoming drug resistance. Researchers evaluated the effect of natural statins (lovastatin, simvastatin, mevastatin, and pravastatin) and synthetic statins (atorvastatin and fluvastatin) on the chemoresistance of chemotherapeutic drugs such as doxorubicin, paclitaxel, and 5-fluorouracil (5-FU) in human myeloid leukemia cells. For example, natural statins such as simvastatin, mevastatin, lovastatin, and pravastatin have shown promising effects on enhancing the cytotoxicity of doxorubicin, paclitaxel, and 5-fluorouracil (5-FU) compared with synthetic statins (fluvastatin and atorvastatin) through the suppression of NF- $\kappa B$ activity in human myeloid leukemia [109]. YAP and TAZ oncoproteins induce drug resistance (doxorubicin and paclitaxel) in various cancers. Fluvastatin has been shown to improve resistance to doxorubicin and paclitaxel in breast cancer cells, which exhibit a higher expression of YAP and TAZ. Overcoming the resistance is attributed to the inhibition of target genes and nuclear localization of YAP and TAZ [110]. Furthermore, the combination of statins (fluvastatin and atorvastatin) with chemotherapeutic drugs such as doxorubicin, paclitaxel, or topotecan inhibits cell proliferation and increases toxicity in leukemia cells; this effect is due to the inhibition of ERK MAP kinase [111].

\subsection{5-Fluorouracil (5-FU) and Capecitabine}

5-fluorouracil is an antimetabolite that inhibits the cell growth by interfering with DNA synthesis and mRNA translation [112]. Lovastatin increases the efficacy of 5-fluorouracil (5-FU) even at low doses $(1-10 \mu \mathrm{M})$; 5 -FU at this dose is unable to inhibit the viability of colorectal cancer cells [61], and the dose of 5-FU at 1-10 $\mu \mathrm{M}$ is clinically relevant in a patient, resulting in an approximate level of $6-12 \mu \mathrm{M}$ in the serum [113] and 2-5 $\mu \mathrm{M}$ in tissues [114]. Cerivastatin is cytotoxic to colorectal cancer cells that are both sensitive and resistant to 5-fluorouracil (5-FU); however, higher efficacy is observed in resistant cells, and the efficacy of cerivastatin in overcoming 5-FU-resistance is partially independent of the mevalonate pathway [115]. In 5-FU-resistant colorectal cancer cells, simvastatin synergistically sensitized colorectal cancer cells to fluorouracil treatment by inducing diverse actions such as anti-inflammation, anti-angiogenic, antioxidant, and by inhibiting tumor metastasis and invasion [116]. 
Simvastatin sensitizes gastric cancer to capecitabine in human gastric cancer xenografts by inhibiting NF- $\mathrm{kB}$ activation and abrogation of cyclin D1, cyclooxygenase-2 (COX-2), survivin, Bcl-2, CXC motif receptor 4, and MMP-9 [117].

\subsection{Sorafenib}

Sorafenib is a protein kinase inhibitor with activity against diverse protein kinases such as VEGFR, PDGFR, and RAF [118]. Fluvastatin enhances the cytotoxic effect of sorafenib by modulating JNK and Akt signaling in melanoma cells [119]. In hepatocellular carcinoma (HCC), hypoxia causes sorafenib resistance by activating YAP, leading to the upregulation of survival genes [120]. Fluvastatin combination with sorafenib inhibits hepatic stellate cell activation and Toll-like receptor 4 (TLR-4)-mediated MAPK and NF- $\mathrm{B}$ activation and decreases stromal cell-derived factor $1 \alpha$, leading to a decrease in cell viability and induction in apoptosis [121]. Atorvastatin also ameliorated hypoxia resistance and increased the sensitivity of hypoxic HCC cells to sorafenib treatment [120]. Further, the treatment with simvastatin has improved sorafenib resistance via suppression of HIF$\alpha 1 /$ PPAR- $\gamma /$ PKM2 signaling [122]. In a phase II clinical trial, a combination of pravastatin with sorafenib was safe and well-tolerated with prolonged time to progression (TTP) in advanced hepatocellular carcinoma [123].

\subsection{Gefitinib, Erlotinib, and Imatinib}

Gefitinib acts by inhibiting EGFR and the amplification and mutation of EGFR in glioblastoma render it resistant to the clinical effects of the EGFR inhibitor gefitinib and the EGFR-targeting antibody cetuximab [124,125]. Targeting HMG-CoA using lovastatin enhances the sensitivity of glioblastoma cells to gefitinib, and the synergistic effect was found to be independent of the status of EGFRvIII and PTEN [126]. In vitro and in vivo studies of human cholangiocarcinoma showed that lovastatin overcomes gefitinib resistance by upregulating tumor necrosis factor- $\alpha$ (TNF- $\alpha)$ [127]. Mutation in the K-Ras gene accounts for $20 \%$ to $30 \%$ of non-small cell lung carcinomas (NSCLCs) associated with gefitinib resistance [128], and administration of lovastatin with gefitinib inhibits growth and induces apoptosis and DNA fragmentation by downregulating RAF/ERK and the Akt pathway [129].

EGFR mutation is also the major cause of drug resistance in non-small cell lung carcinoma treated with inhibitors; gefitinib and erlotinib because of the induction of survivin and survivin-mediated mutation at T790 of EGF. Simvastatin overcomes this resistance and induces apoptosis by suppressing Akt/ $\beta$-signaling [130]. Furthermore, it restores gefitinib-suppressed BIM expression, increasing sensitivity to gefitinib in nonsmall cell lung carcinoma [131]. Atorvastatin reverses gefitinib resistance in KRAS-mutant non-small cell lung carcinoma, irrespective of PIK3CA and PTEN status [132].

Both statins (pitavastatin and fluvastatin) activate apoptosis in non-small cell lung carcinoma (NSCLC), and the combination of pitavastatin with EGFR tyrosine kinase inhibitor (erlotinib) synergistically increased pitavastatin cytotoxicity in K-ras mutated cells [133].

Lovastatin increases the sensitivity and efficacy of imatinib in melanoma by blocking the ABC transporter-mediated efflux of imatinib, which leads to an increase in the intracellular level of imatinib [134]. Simvastatin shows higher efficacy in imatinib-resistant chronic myelogenous leukemia cells than in sensitive cells via suppression of tyrosine phosphorylation and activation of STAT3 and STAT5, leading to cell-cycle arrest and apoptosis induction [135].

\subsection{Cisplatin}

Cisplatin interlinks with the purine bases on the DNA; interfering with DNA repair mechanisms, causing DNA damage [136]. Simvastatin induces glutathione (GSH)mediated suppression of ABCG4 (which causes efflux of intracellular doxorubicin and cisplatin) levels, increasing the sensitivity of prostate cancer cells to cisplatin and leading to the suppression of tumor growth [98]. Atorvastatin sensitizes the anti-cancer effect of 
cisplatin in human osteosarcoma by suppressing matrix metalloprotease 2 (MMP2) induced by cisplatin [100]. Cerivastatin enhances the anti-tumor activity of cisplatin against human breast cancer cells [101]. Along with cisplatin, lovastatin synergistically suppressed gall bladder cancer growth through inhibition of the mevalonate pathway [137]. In cisplatinresistant prostate and cervical cancer cells, lovastatin overcomes resistance by upregulating tumor suppressor genes such as Ras homolog family member B (RHOB) and kruppel-like factor 2 (KLF2) and 6 (KLF6) [138]. Pitavastatin significantly enhances the efficacy of cisplatin in lung cancer cells and its tumor xenograft model without causing toxicity in mice; this effect is mediated by the suppression of Ras/Raf/MEK and PI3K/Akt/mTOR signaling [139].

\subsection{Gemcitabine}

Gemcitabine inhibits the DNA synthesis process [140]. Pancreatic cancer cells show poor response to gemcitabine treatment. However, treatment with gemcitabine in combination with statins, such as simvastatin, atorvastatin, rosuvastatin, fluvastatin, pitavastatin, and pravastatin is an effective treatment for pancreatic cancers, particularly gemcitabineresistant cancer [141]. Furthermore, it synergistically improved the anti-cancer efficacy of gemcitabine in human cholangiocarcinoma cells [142]. The synergistic anti-cancer effect of gemcitabine and pitavastatin on pancreatic ductal adenocarcinoma (PDAC) is mediated by cell-cycle arrest at sub-G1 and S phases, leading to downregulation of cyclin A2/CDK2 and upregulation of $\mathrm{p} 21 / \mathrm{p} 27$. Furthermore, activated autophagy was observed to be involved in the cell death mechanism [143]. Pancreatic ductal adenocarcinoma (PDAC) resistance to gemcitabine is attenuated by simvastatin via suppression of TAM-mediated suppression of Gfi-1 and induction of CTGF and HMG $\beta 1$ [144].

\subsection{Vemurafenib}

Vemurafenib is the selective inhibitor of BRAF kinase leading to the aberrant mitogenactivated protein kinase (MAPK) pathway [145]. Simvastatin has shown promising effects in overcoming drug resistance to diverse anticancer drugs in different cancer cells. For example, simvastatin, by inhibiting RAS or BRAF signaling, reversed vemurafenib resistance developed through activation of RAS or BRAF in mutant melanoma [146]. Simvastatin improved the inefficiency of vemurafenib (BRAF inhibitor) or selumetinib (MEK inhibitor) as an anti-cancer agent in MAPK mutant melanoma by inhibiting isoprenoid synthesis [147]. The efficacy of vemurafenib in the treatment of metastatic melanoma has been decreasing owing to the development of resistance, which was observed to be inhibited by fluvastatin treatment. The inhibitory effect of fluvastatin on vemurafenib resistance is mediated by the inhibition of the PI3K/Akt pathway [148].

\subsection{TRAIL}

Lovastatin synergistically enhances the efficacy of TNF-related apoptosis-inducing ligand (TRAIL) in human refractory prostate cancer cells via the upregulation of death receptor 4 (DR4) [149]. In addition, statins increase prostate-restricted replication component adenovirus (PRRA) replication, CAR, integrin, and death receptor 4 (DR4), leading to cholesterol depletion and increased TRAIL sensitivity [149]. Activation of PI3K/Akt signaling causes breast cancer resistance to MEK inhibition therapy by CH5126766 or trametinib. Treatment with simvastatin or fluvastatin overcomes this resistance by suppressing PI3K/Akt signaling and upregulating TRAIL [150]. In addition, sensitivity to sorafenib is enhanced by the inhibition of toll-like receptor 4 (TLR4)-mediated MAPK and NF- $\mathrm{KB}$ activation [121]. In addition, apoptotic resistance to MEK inhibitors is overcome by the inhibition of Akt activation and induction of TNF-related apoptosis-inducing ligand (TRAIL) [150]. 


\subsection{Prednisolone}

Although pitavastatin is considered to exhibit potential for use in the treatment of ovarian cancers, the necessity of a high dose of statin increases the risk of myopathy, the most common adverse effect associated with statins. Therefore, the reduction of statin dose is mandatory. Prednisolone was observed to be effective in synergizing the anti-cancer effect of pitavastatin. The use of pitavastatin combined with prednisolone decreases the expression of genes involved in the mevalonate pathway, such as mevalonate decarboxylase (MVD), farnesyl diphosphate synthase (FDPS), geranylgeranyltransferase I and II (GGTI, GGTII), and isopentenyl diphosphate isomerase (IDI1) [151].

Table 2. In vitro study of statins showing the synergistic action in combination with anti-cancer drugs to overcome anti-cancer therapy resistance.

\begin{tabular}{|c|c|c|c|c|c|}
\hline $\begin{array}{c}\text { Cancer } \\
\text { Types/Cells }\end{array}$ & Statin & $\begin{array}{l}\text { Concurrent } \\
\text { Therapy }\end{array}$ & Statin Dose & Pathway & Ref \\
\hline Colorectal cancer & \multirow{11}{*}{ Lovastatin } & - & $2 \mu \mathrm{M}$ & $\begin{array}{c}\text { Inhibits DNMT and } \\
\text { demethylates the BMP2, } \\
\text { TIMP3, and HIC1 promoters }\end{array}$ & [61] \\
\hline Breast cancer & & - & $4,8,16 \mu \mathrm{M}$ & $\begin{array}{l}\text { Cell cycle arrest at } G(0) / G(1) \\
\text { phase }\end{array}$ & [62] \\
\hline $\begin{array}{l}\text { MDA-MB-231 } \\
\text { breast cancer }\end{array}$ & & - & $1-10 \mu \mathrm{M}$ & $\begin{array}{c}\text { Upregulates Raf1, amyloid } \beta \text {, } \\
\text { MEK6, STAT1, } \\
\text { myelin-oligodendrocyte } \\
\text { glycoprotein, Vitamin D3 } \\
\text { receptor, downregulates } \\
\text { CREB, and } \gamma \text { glutamyl } \\
\text { transferase }\end{array}$ & [63] \\
\hline Glioblastoma & & Gefitinib & $10 \mu \mathrm{M}$ & Decreases Akt & [126] \\
\hline $\begin{array}{c}\text { Human } \\
\text { cholangiosarcoma }\end{array}$ & & Gefitinib & $5-10 \mu \mathrm{M}$ & $\begin{array}{c}\text { Increases cell cycle arrest, } \\
\text { TNF-alpha, and decreases } \\
\text { LKB1 activation }\end{array}$ & [127] \\
\hline $\begin{array}{l}\text { Human non-small } \\
\text { cell lung } \\
\text { carcinoma }\end{array}$ & & Gefitinib & $1-5 \mu \mathrm{M} 2$ & $\begin{array}{c}\text { Increases PARP, caspase-3, } \\
\text { decreases Bcl-2, RAS, p-RAF, } \\
\text { p-ERK1/2,p-AKT, and } \\
\text { p-EGFR }\end{array}$ & [129] \\
\hline $\begin{array}{l}\text { Chronic myeloid } \\
\text { leukemia }\end{array}$ & & Imatinib & $5-20 \mu \mathrm{M}$ & Decreases ABCB1 and ABCG2 & [134] \\
\hline $\begin{array}{l}\text { Gall bladder } \\
\text { cancer }\end{array}$ & & Cisplatin & $10-50 \mu \mathrm{M}$ & $\begin{array}{l}\text { Impairs DNA damage } \\
\text { response }\end{array}$ & [137] \\
\hline Prostate cancer & & TRAIL & $5 \mu \mathrm{M}$ & $\begin{array}{c}\text { Increases PRRA replication, } \\
\text { CAR, and integrin }\end{array}$ & [149] \\
\hline Glioblastoma & & Temozolomide & $0.625-20 \mu \mathrm{M}$ & Impairs autophagy flux & [152] \\
\hline $\begin{array}{l}\text { Anaplastic thyroid } \\
\text { cancer }\end{array}$ & & Troglitazone & $1-100 \mu \mathrm{M}$ & $\begin{array}{l}\text { Increases cell cycle arrest, p21, } \\
\text { and p27 }\end{array}$ & [153] \\
\hline Multiple myeloma & \multirow{2}{*}{ Pravastatin } & - & $0.3,0.6$, and $0.9 \mu \mathrm{M}$ & $\begin{array}{c}\text { Increases cells in G0/G1 } \\
\text { phase of the cell cycle and } \\
\text { reduces the factors VEGF, and } \\
\text { bFGF }\end{array}$ & [70] \\
\hline Human hepatoma & & - & & $\begin{array}{l}\text { Decreases p38 activity and } \\
\text { expressions of p-p38, RhoC, } \\
\text { and MMP-2, while elevates } \\
\text { MKP-1 expression }\end{array}$ & [71] \\
\hline
\end{tabular}


Table 2. Cont.

\begin{tabular}{|c|c|c|c|c|c|}
\hline $\begin{array}{c}\text { Cancer } \\
\text { Types/Cells }\end{array}$ & Statin & $\begin{array}{l}\text { Concurrent } \\
\text { Therapy }\end{array}$ & Statin Dose & Pathway & Ref \\
\hline Esophageal cancer & & - & $\begin{array}{l}0.625,1.25,2.5,5 \\
\text { and } 10 \mu \mathrm{M}\end{array}$ & $\begin{array}{l}\text { Inhibits PTEN-PI3K/AKT } \\
\text { pathway }\end{array}$ & [69] \\
\hline Cholangiocarcinoma & & - & $\begin{array}{l}1-100 \mu \mathrm{M} \\
25-50 \mu \mathrm{M}\end{array}$ & $\begin{array}{c}\text { Reduces Rac1 activity, lowers } \\
\text { expression of ABCA1 and } \\
\text { ABCG1 }\end{array}$ & {$[65,66]$} \\
\hline Prostate cancer & Simvastatin & Docetaxel & $25 \mu \mathrm{M}$ & $\begin{array}{l}\text { Increases Bad, reduces Bcl-2, } \\
\text { Bcl-xL and cleaved caspases } \\
\text { 9/3, increases TNF, Fas-L, } \\
\text { Traf1, and cleaved caspase } 8\end{array}$ & {$[64]$} \\
\hline Prostate cancer & & Doxorubicin & 2.5-20 $\mu \mathrm{M}$ & Decreases ABGC4 protein & [98] \\
\hline $\begin{array}{l}\text { Malignant } \\
\text { mesothelioma }\end{array}$ & & Doxorubicin & $10 \mu \mathrm{M}$ & $\begin{array}{l}\text { Increases NF-kB and NO } \\
\text { production }\end{array}$ & [102] \\
\hline Colon carcinoma & & $5-\mathrm{FU}$ & $5 \mathrm{mg} / \mathrm{kg}$ & $\begin{array}{c}\text { Decreases tumor angiogenesis, } \\
\text { Bcl-2 and increases Bax }\end{array}$ & [116] \\
\hline $\begin{array}{l}\text { Human salivary } \\
\text { adenoid cystic } \\
\text { carcinoma }\end{array}$ & & $\begin{array}{l}\text { MiR-21 inhibitor } \\
\quad(\mathrm{miR}-21 \mathrm{i})\end{array}$ & $1-100 \mu \mathrm{M}$ & $\begin{array}{l}\text { Decreases N-Cadherin and } \\
\text { increases E-Cadherin, } \\
\text { decreases in Bcl-2 and } \\
\text { survivin, while increase in } \\
\text { p53, Bax, and caspase-9 }\end{array}$ & [67] \\
\hline $\begin{array}{l}\text { Pancreatic ductal } \\
\text { carcinoma }\end{array}$ & \multirow{10}{*}{ Simvastatin } & Gemcitabine & $5-40 \mu \mathrm{M}$ & $\begin{array}{c}\text { Increases Gfi-1, decreases } \\
\text { CTGF }\end{array}$ & [144] \\
\hline $\begin{array}{c}\text { Chronic myeloid } \\
\text { leukemia }\end{array}$ & & Imatinib & $10-50 \mu \mathrm{M}$ & $\begin{array}{l}\text { Increases cell cycle arrest, } \\
\text { decreases STAT5 and STAT3 }\end{array}$ & [135] \\
\hline $\begin{array}{l}\text { Metastatic } \\
\text { melanoma }\end{array}$ & & Dacarbazine & $0.5-1 \mu \mathrm{M}$ & $\begin{array}{c}\text { Decreases RhoA/RhoC/LIM, } \\
\text { increases p53, p21, p27, casp-3, } \\
\text { and PARP }\end{array}$ & [154] \\
\hline Breast cancer & & Pentoxifylline & $0.1-50 \mu \mathrm{M}$ & $\begin{array}{c}\text { Increases apoptosis, } \\
\text { autophagy, and cell cycle } \\
\text { arrest }\end{array}$ & [155] \\
\hline Prostate cancer & & Castration & $0.1-20 \mu \mathrm{M}$ & $\begin{array}{l}\text { Increases cell cycle arrest, } \\
\text { apoptosis, and decreases Akt }\end{array}$ & [156] \\
\hline Blood cancer & & Ventoclax & $5-20 \mu \mathrm{M}$ & Increases p53, PUMA & [157] \\
\hline $\begin{array}{l}\text { Non-small cell } \\
\text { lung cancer }\end{array}$ & & Gefitinib, Erlotinib & $5 \mu \mathrm{M}$ & $\begin{array}{l}\text { Decreases Akt, b-catenin, } \\
\text { survivin, cyclin D1 }\end{array}$ & [130] \\
\hline $\begin{array}{c}\text { Gastric cancer } \\
\text { xenograft }\end{array}$ & & Capecitbine & $10-50 \mu \mathrm{M}$ & Decreases NF-kB & [117] \\
\hline Melanoma cells & & $\begin{array}{c}5,6- \\
\text { dimethylsanthenone- } \\
\text { 4-acetic } \\
\text { acid }\end{array}$ & $1.5-14 \mu \mathrm{M}$ & Decreases HIF-alpha & [158] \\
\hline Breast cancer & & Anti-HER2 & $1-5 \mu \mathrm{M}$ & Decreases YAP/TAZ signaling & [159] \\
\hline Colon cancer & $\begin{array}{l}\text { Simvastatin + } \\
\text { phenoth- } \\
\text { iazines }\end{array}$ & Doxorubicin & $2.5 \mu \mathrm{M}$ & $\begin{array}{c}\text { Decreases ABCB1, COX-2 } \\
\text { enzymes, Bcl-2 and increases } \\
\text { Bax }\end{array}$ & [103] \\
\hline
\end{tabular}


Table 2. Cont

\begin{tabular}{|c|c|c|c|c|c|}
\hline $\begin{array}{c}\text { Cancer } \\
\text { Types/Cells }\end{array}$ & Statin & $\begin{array}{l}\text { Concurrent } \\
\text { Therapy }\end{array}$ & Statin Dose & Pathway & Ref \\
\hline $\begin{array}{l}\text { Human myeloid } \\
\text { leukemia }\end{array}$ & $\begin{array}{l}\text { Simvastatin, } \\
\text { Mevastatin, } \\
\text { Lovastatin, } \\
\text { Pravastatin }\end{array}$ & $\begin{array}{c}\text { Doxorubicin, } \\
\text { Paclitaxel, 5-FU }\end{array}$ & $5-50 \mu \mathrm{M}$ & Decreases NF-kB & [109] \\
\hline Pancreatic cancer & $\begin{array}{l}\text { Simvastatin + } \\
\text { bisphospho- } \\
\text { nates }\end{array}$ & Gemcitabine & $0.1-100 \mu \mathrm{M}$ & Decreases cell viability & [141] \\
\hline Colon cancer & $\begin{array}{c}\text { Simvastatin + } \\
\text { Oxicam } \\
\text { derivatives }\end{array}$ & Doxorubicin & $5 \mu \mathrm{M}$ & $\begin{array}{c}\text { Increases caspase-3, Bax, } \\
\text { decreases Bcl-2 and COX-2 }\end{array}$ & [107] \\
\hline Prostate cancer & $\begin{array}{l}\text { Simvastatin + } \\
\text { Valproic acid }\end{array}$ & Docetaxel & $1-100 \mu \mathrm{M}$ & Decreases YAP & [160] \\
\hline $\begin{array}{c}\text { Acute myeloid } \\
\text { leukemia (AML), }\end{array}$ & \multirow{8}{*}{ Fluvastatin } & $\begin{array}{l}\text { Tyrosine kinase } \\
\text { inhibitor } \\
\text { (lestaurtinib) }\end{array}$ & $0.2-2 \mu \mathrm{M}$ & Inhibits FLT3 glycosylation & [73] \\
\hline C6 glioma cell line & & - & 1 to $10 \mu \mathrm{M}$ & $\begin{array}{l}\text { Decreases p-ERK1/2 } \\
\text { expression, upregulates } \\
\text { p-JNK1/2, and reduces } \\
\text { MMP-9 and VEGF } \\
\text { concentrations }\end{array}$ & [76] \\
\hline Breast cancer & & - & $5-20 \mu \mathrm{M}$ & Downregulates vimentin, & [79] \\
\hline Breast cancer & & - & $10 \mu \mathrm{M}$ & $\begin{array}{c}\text { Increases p53 and induces } \\
\text { autophagy }\end{array}$ & [81] \\
\hline $\begin{array}{l}\text { Human hepatoma } \\
\text { cells (HepG2) }\end{array}$ & & $\begin{array}{l}\text { Trans-activator } \\
\text { transcription } \\
\text { peptide (TAT) }\end{array}$ & $1-1000 \mu \mathrm{M}$ & $\begin{array}{l}\text { Accumulates cells in the } \\
\text { pre-G phase }\end{array}$ & [82] \\
\hline Melanoma cells & & Sorafenib & $1 \mu \mathrm{M}$ & Increases PARP, and JNK & [119] \\
\hline $\begin{array}{l}\text { Hepatocellular } \\
\text { carcinoma }\end{array}$ & & Sorafenib & $10 \mathrm{mg} / \mathrm{kg}$ & Inactivates MAPK and NF-kB & [121] \\
\hline Melanoma cells & & Vemurafenib & $1-10 \mu \mathrm{M}$ & Decreases Akt & [148] \\
\hline Cervical cancer & $\begin{array}{l}\text { Fluvastatin, } \\
\text { Atorvastatin, } \\
\text { and } \\
\text { simvastatin }\end{array}$ & - & $10-160 \mu \mathrm{M}$ & $\begin{array}{l}\text { Increases ROS and nitrite } \\
\text { production }\end{array}$ & [75] \\
\hline Lymphoma cells & $\begin{array}{l}\text { Fluvastatin, } \\
\text { atorvastatin, } \\
\text { and } \\
\text { simvastatin }\end{array}$ & - & $0-5 \mu \mathrm{M}$ & $\begin{array}{c}\text { Enhances the DNA } \\
\text { fragmentation and the } \\
\text { activation of proapoptotic } \\
\text { members such as caspase-3, } \\
\text { PARP and Bax, increases } \\
\text { reactive oxygen species (ROS), } \\
\text { p38 MAPK activation but } \\
\text { suppresses activation of } \\
\text { anti-apoptotic molecule Bcl-2, } \\
\text { decrease mitochondrial } \\
\text { membrane potential and } \\
\text { activation of Akt and Erk } \\
\text { pathways }\end{array}$ & [78] \\
\hline
\end{tabular}


Table 2. Cont

\begin{tabular}{|c|c|c|c|c|c|}
\hline $\begin{array}{c}\text { Cancer } \\
\text { Types/Cells }\end{array}$ & Statin & $\begin{array}{l}\text { Concurrent } \\
\text { Therapy }\end{array}$ & Statin Dose & Pathway & Ref \\
\hline $\begin{array}{l}\text { Human breast } \\
\text { cancer }\end{array}$ & $\begin{array}{l}\text { Fluvastatin } \\
\quad \text { and } \\
\text { atorvastatin }\end{array}$ & Estradiol & - & $\begin{array}{l}\text { Deregulates Bcl-2 rather than } \\
\text { up-regulation of Fas-L or p53 }\end{array}$ & [74] \\
\hline Breast cancer & $\begin{array}{c}\text { Fluvastatin } \\
\text { and } \\
\text { simvastatin }\end{array}$ & - & 10 to $20 \mu \mathrm{M}$ & $\begin{array}{l}\text { Increases nitric oxide levels } \\
\text { via iNOS expression, increases } \\
\text { MnSOD, catalase and GSH } \\
\text { which in turn, diminished } \\
\text { H2O2 levels, down regulates } \\
\text { transferrin receptor (TfR1), } \\
\text { TfR1, MMP-2, } 9\end{array}$ & [79] \\
\hline $\begin{array}{l}\text { glioblastoma cell } \\
\text { lines }\end{array}$ & $\begin{array}{l}\text { Fluvastatin, } \\
\text { cerivastatin, } \\
\text { and } \\
\text { pitavastatin }\end{array}$ & - & $\begin{array}{c}\text { IC50 value: } \\
\text { Ceri:0.0010 } \mu \mathrm{M} \\
\text { Pita:0.0023 } \mu \mathrm{M} \\
\text { Flu:0.109 } \mu \mathrm{M}\end{array}$ & Increase autophagy & [80] \\
\hline Breast cancer & $\begin{array}{c}\text { Fluvastatin } \\
\text { and } \\
\text { simvastatin }\end{array}$ & $\begin{array}{l}\text { CH51126766 or } \\
\text { trametinib }\end{array}$ & $0.3 \mu \mathrm{M}$ & $\begin{array}{c}\text { Decreases Akt and increases } \\
\text { PARP }\end{array}$ & [150] \\
\hline $\begin{array}{l}\text { Non-small cell } \\
\text { lung cancer }\end{array}$ & $\begin{array}{c}\text { Fluvastatin } \\
\text { and } \\
\text { pitavastatin }\end{array}$ & Erlotinib & $100 \mu \mathrm{M}$ & Increases casp- 3 and PARP & [133] \\
\hline Cervical cancer & & - & $10-160 \mu \mathrm{M}$ & $\begin{array}{l}\text { Increases ROS and nitrite } \\
\text { production }\end{array}$ & [75] \\
\hline Lymphoma cells & $\begin{array}{l}\text { Fluvastatin, } \\
\text { atorvastatin, } \\
\text { and } \\
\text { simvastatin }\end{array}$ & - & $0-5 \mu \mathrm{M}$ & $\begin{array}{c}\text { Enhances DNA fragmentation, } \\
\text { caspase-3, PARP and Bax, but } \\
\text { suppresses Bcl-2, increases } \\
\text { reactive oxygen species (ROS) } \\
\text { and activation of p38 MAPK, } \\
\text { decreases mitochondrial } \\
\text { membrane potential and } \\
\text { activation of Akt and Erk } \\
\text { pathways }\end{array}$ & [78] \\
\hline $\begin{array}{c}\text { NCI-H332M, } \\
\text { DU-145, PC-3 and } \\
\text { HOP-92 cell lines }\end{array}$ & & - & $0-30 \mu \mathrm{M}$ & Inhibits protein prenylation & [83] \\
\hline $\begin{array}{c}\text { Human } \\
\text { osteosarcoma }\end{array}$ & & $\begin{array}{l}\text { Doxorubicin and } \\
\text { cisplatin }\end{array}$ & $10 \mu \mathrm{M}$ & Decreases MMP2 & [100] \\
\hline $\begin{array}{l}\text { Hepatocellular } \\
\text { carcinoma }\end{array}$ & & Hypoxia & $1-10 \mu \mathrm{M}$ & Inactivates YAP & [120] \\
\hline $\begin{array}{l}\text { Human cholangio- } \\
\text { carcinoma }\end{array}$ & Atorvastatin & Gemcitabine & 5-100 $\mu \mathrm{M}$ & $\begin{array}{l}\text { Decreases Yes-associated } \\
\text { protein }\end{array}$ & [142] \\
\hline $\begin{array}{l}\text { Non-small cell } \\
\text { lung cancer }\end{array}$ & & Gefitinib & $1-5 \mu \mathrm{M}$ & Decreases Akt and ERK & [132] \\
\hline Melanoma cancer & & Tamoxifen & $1-100 \mu \mathrm{M}$ & $\begin{array}{l}\text { Increases Bax and } \\
\text { cytochrome } C\end{array}$ & [161] \\
\hline Colon cancer & & Celecoxib & $15-45 \mu \mathrm{M}$ & $\begin{array}{c}\text { Increases cell cycle arrest and } \\
\text { apoptosis }\end{array}$ & [162] \\
\hline
\end{tabular}


Table 2. Cont.

\begin{tabular}{|c|c|c|c|c|c|}
\hline $\begin{array}{c}\text { Cancer } \\
\text { Types/Cells }\end{array}$ & Statin & $\begin{array}{l}\text { Concurrent } \\
\text { Therapy }\end{array}$ & Statin Dose & Pathway & Ref \\
\hline Prostate cancer & \multirow{5}{*}{ Rosuvastatin } & - & $5-50 \mu \mathrm{M}$ & $\begin{array}{l}\text { Decreases Vimentin and } \\
\text { Zeb-1, and inhibits spheroid } \\
\text { formation }\end{array}$ & [84] \\
\hline Hepatic cancer & & NA & $\begin{array}{l}\text { The IC50 values } \\
\text { ranged from } 12 \text { to } \\
112 \mu \mathrm{g} / \mathrm{mL}\end{array}$ & $\begin{array}{c}\text { Enhances apoptosis and } \\
\text { induces cell cycle arrest at } \\
\text { G2/M phase }\end{array}$ & [87] \\
\hline $\begin{array}{l}\text { Murine mammary } \\
\text { adenocarcinoma }\end{array}$ & & Nilotinib & $7.5 \mathrm{mg} / \mathrm{kg}$ & $\begin{array}{c}\text { Increases caspase } 3 \text {, decreases } \\
\text { ER alpha, and tumor nitric } \\
\text { oxide level }\end{array}$ & [163] \\
\hline $\begin{array}{l}\text { Hepatocellular } \\
\text { carcinoma }\end{array}$ & & Dasatinib & $10,25,50 \mu \mathrm{M}$ & $\begin{array}{c}\text { Decreases p-FAK/p-Src, } \\
\text { p-Ras/p-Raf, p-STAT3, p-Akt, } \\
\text { HGF, VEGF, MMP-9, and Ki67 }\end{array}$ & [164] \\
\hline $\begin{array}{l}\text { Adrenocortical } \\
\text { carcinoma }\end{array}$ & & Mitotane & $100 \mu \mathrm{M}$ & $\begin{array}{c}\text { Decreases cell viability, } \\
\text { ABCA1 and induces apoptosis }\end{array}$ & [165] \\
\hline Ovarian cancer & \multirow{5}{*}{ Pitavastatin } & - & $1 \mu \mathrm{M}$ & $\begin{array}{l}\text { Increases caspase activity and } \\
\text { apoptotic cell death }\end{array}$ & [89] \\
\hline $\begin{array}{l}\text { Oral squamous cell } \\
\text { carcinoma }\end{array}$ & & - & $0.05-0.25 \mu \mathrm{M}$ & $\begin{array}{c}\text { Increases p-AMPK, FOXO3a, } \\
\text { and PUMA while decreases } \\
\text { p-Akt }\end{array}$ & [90] \\
\hline $\begin{array}{c}\text { Breast and } \\
\text { melanoma model }\end{array}$ & & Radiation & $1.25,2.5$ or $5 \mu \mathrm{M}$ & $\begin{array}{l}\text { Increases senescence and } \\
\text { delays DNA repair }\end{array}$ & [91] \\
\hline $\begin{array}{l}\text { Pancreatic ductal } \\
\text { carcinoma }\end{array}$ & & Gemcitabine & $0.5 \mu \mathrm{M}$ & $\begin{array}{l}\text { Increases caspase-3, PARP, } \\
\text { RIP1-RIP3-MLKL complex, } \\
\text { decreases cyclineA2/CDK2, } \\
\text { increases p21 }\end{array}$ & [143] \\
\hline Melanoma & & Dacarbazine & $1 \mu \mathrm{M}$ & $\begin{array}{l}\text { Increases apoptosis and } \\
\text { autophagy cell death }\end{array}$ & [166] \\
\hline Breast cancer & \multirow{5}{*}{ Cerivastatin } & - & $25 \mathrm{ng} / \mathrm{mL}$ & $\begin{array}{l}\text { Down-regulates cyclin D1, } \\
\text { PCNA, c-myc, and } \\
\text { up-regulates p21, p19INK4d, } \\
\text { integrin h8, (decrease in u-PA, } \\
\text { MMP-9, u-PAR, PAI-1 and } \\
\text { increase in anti-oncogenes } \\
\text { Wnt-5a and H-cadherin }\end{array}$ & [92] \\
\hline $\begin{array}{c}\text { Human } \\
\text { glioblastoma }\end{array}$ & & - & $10-100 \mu \mathrm{M}$ & $\begin{array}{l}\text { Down-regulates tyrosine } \\
\text { phosphorylation of FAK }\end{array}$ & [93] \\
\hline Breast cancer & & NA & $25 \mathrm{ng} / \mathrm{mL}$ & $\begin{array}{l}\text { Induces cell cycle arrest at } \\
\text { G1/S, inactivates Rho, NF-kB, } \\
\text { and decreases MMP-9 }\end{array}$ & [94] \\
\hline Breast cancer & & $\begin{array}{l}\text { Doxorubicin and } \\
\text { cisplatin }\end{array}$ & $0.0195-0.624 \mu \mathrm{M}$ & Increases p21 & [101] \\
\hline Colorectal cancer & & 5-FU & $0.01-10 \mu \mathrm{M}$ & $\begin{array}{l}\text { Decreases nuclear factor kB } \\
\text { binding activity }\end{array}$ & [115] \\
\hline $\begin{array}{l}\text { Malignant } \\
\text { mesothelioma }\end{array}$ & Mevastatin & Doxorubicin & $100 \mu \mathrm{M}$ & $\begin{array}{l}\text { Increases NF-kB and NO } \\
\text { production }\end{array}$ & [102] \\
\hline
\end{tabular}

\section{The Dark Side of Statin Therapy (Resistance and Intolerance to Statins)}

Although statins have demonstrated anti-cancer effects under different conditions, they produce an unexpected effect in cancer treatment. Statin itself can induce resistance. The effect of statins on the regulation of multidrug resistance proteins was studied 
in vitro in hepatocytes, where statins (pitavastatin) help in the excretion of endogenous and exogenous lipophilic compounds from hepatocytes via multidrug resistance protein 2 (MDR2) expression [167]. Another in vitro study shows that fluvastatin causes resistance in cells comprised of hepatitis $C$ virus replicon via an increase in HMG-CoA reductase and P-gp expression [168]. In prostate cancer xenograft model, combined treatment with a lipid-lowering drug, ezetimibe, and simvastatin increases tumor growth along with the induction of low-density lipoprotein (LDL) receptor; however, the serum cholesterol level decreases, suggesting that the induction of LDL receptor can be a possible mechanism of resistance development under these treatments [169]. The insensitivity of breast cancer cells to atorvastatin treatment was determined to be due to increased unsaturated fatty acid metabolism and cholesterol biosynthesis through the induction of stearoyl-CoA desaturase (SCD) and 3-hydroxy03-methylglutaryl-CoA reductase (HMGCR), respectively [170]. Breast cancer cells show different vulnerabilities to statins (atorvastatin, simvastatin, and rosuvastatin). For example, breast cancer cells, such as MDA-MB-231 and MDA-MB-468, show sensitivity, while T47D and MCF-7 cells show resistance. The development of statin resistance in T47D and MCF-7 cells is due to sterol regulatory element-binding protein (SREBP-2)-mediated induction of HMGCR mRNA and protein expression [171]. Along with the induction of cytotoxicity in breast cancer cells, lovastatin causes autophagy flux, as well as induction of the multidrug resistance proteins MDR1 and TGF- $\beta 1$, indicating the possibility of resistance development. However, the inhibition of autophagy flux by treatment with chloroquine decreased the expression of MDR1 and TGF- $\beta 1$, demonstrating that lovastatin can cause breast cancer cell resistance by inducing the autophagy flux [172] The clinical study shows that statin resistance and intolerance are associated with polymorphisms in genes such as HMG-CoA reductase, TNF- $\alpha$, BCRP/ABCG2, P-gp/ABCB1, MRP1/ABCC1, MRP2 / ABCC2, CETP, ApoE, PCSK9, RHOA, CYP7A1, LDLR, LPA, OATP, NPC1L1, and FXR [173].

\section{Statin-Mediated Resistance}

One of the mechanisms through which statins induce resistance development is the expression of MDR2 proteins. For example, the activation of the liver X-receptor (LXR) $\alpha / \beta$, SREBP-1, and HMGCR expression have been involved leading to the induction of MDR2 $[167,171]$. The induction of the LDL receptor is another factor to increase tumor growth, along with the development of resistance [169]. The induction of the stearoyl-CoA desaturase (SCD) and HMGCR under statin treatment leads to resistance by an increase in unsaturated fatty acid metabolism and cholesterol biosynthesis [170]. Furthermore, according to clinical data polymorphisms of the genes such as HMG-CoA reductase, TNF$\alpha$, BCRP/ABCG2, P-gp/ABCB1, MRP1/ABCC1, MRP2/ABCC2, CETP, ApoE, PCSK9, RHOA, CYP7A1, LDLR, LPA, OATP, NPC1L1, and FXR have been linked to statin resistance an intolerance [173].

\section{A Clinical Trial of Statin in Cancer}

The epidemiologic study has proved that the use of hydrophobic statin (simvastatin, lovastatin, Fluvastatin) but not hydrophilic statins (pravastatin and atorvastatin) have been associated with the reduced breast cancer risk [174]. In a continuing study, the first clinical trial of simvastatin in refractory multiple myeloma was done in 2007. Simvastatin was administered to refractory multiple myeloma patients with the concomitant administration of two cycles of bortezomib or bendamustine. The use of simvastatin was well tolerated without grade $3 / 4$ toxicity, and patients administered with simvastatin showed a reduction in bortezomib or bendamustine resistance through inhibition of HMG-CoA reductase [46], suggesting that the simvastatin helps to improve the efficacy of bortezomib or bendamustine in these conditions. A phase II clinical trial was performed in metastatic colorectal cancer patients with KRAS mutations for evaluating the safety and efficacy of the combination of simvastatin with cetuximab in patients who were previously exposed to fluoropyrimidine, oxaliplatin, and irinotecan. The clinical data showed that only 4 out 
of $18(22.2 \%)$ patients were free from progression at the primary end point at 20.3 to 47 weeks [48].

The clinical study of other statins, i.e., atorvastatin and fluvastatin, was conducted in 9135 subjects with chronic hepatitis C virus (HCV) from 2001 to 2014, and the result shows that the use of statins reduced the risk of fibrosis progression and caused a $49 \%$ reduction in the incidence of hepatocellular carcinoma. The reduction of HCC by statin is believed to be due to the inhibition of thioredoxin, a hepatic enzyme, increased in pre-malignant hepatic nodule to mediate cell survival [175].

A pilot window-of-opportunity study of fluvastatin shows that in 33 men with prostate cancer, the use of fluvastatin before radical prostatectomy (RP) increased prostate cancer cell death with an increase in cleaved caspase-3 without alteration in intratumoral ki67, a marker of cancer [50], suggesting that the use of fluvastatin prior to RP improves the effect on tumor cells apoptosis. The phase I clinical trial was performed to determine the safety and dose of rosuvastatin in patients with advanced solid malignancies in which a dose of rosuvastatin (1-8 mg/kg/day) in combination with erlotinib was used. Although the combination has shown the observed disease stabilization rate of $25 \%$, the high level of muscle toxicities including fatigue, muscle weakness, and myalgia have been detected limiting the use of rosuvastatin in combination with erlotinib [52]. However, a randomized, single-blind, placebo-controlled trial has indicated that rosuvastatin can be used to inhibit chemotherapy-induced cardiotoxicity in woman with breast cancer [53].

In a phase II clinical trial, a combination of pravastatin with sorafenib was safe and well-tolerated with prolonged time to progression (TTP) in advanced hepatocellular carcinoma [123]. A pooled analysis of metastatic renal cell carcinoma (mRCC) treated on phase II and phase III clinical trials by sunitinib, sorafenib, axitinib, temsirolimus, temsirolimus + interferon (IFN)- $\alpha$, bevacizumab + temsirolimus, bevacizumab + IFN$\alpha$, or IFN- $\alpha$, along with or without statin were evaluated with overall survival. The data showed that the use of statins along with other anti-cancer adjuvants increased the overall survival to 25.6 months compared to treatment without statins, which resulted in survival of 18.9 months [176]. Further, the retrospective study showed that the use of statin is associated with improved overall survival in gemcitabine-erlotinib combination chemotherapy in patients with advanced pancreatic cancer [47]. A nationwide, populationbased case-control study conducted in Taiwan in lung cancer patients receiving EGFRTKIs therapy has shown that the use of statin reduces the risk of death with significant increase in median progression-free survival (8.3 months vs 6.1 months) and median overall survival (35.5 months vs. 23.9 months) [177]. However, certain clinical studies have demonstrated the inefficient use of statins in clinical trials. For example, the use of pravastatin together with cyclosporine $\mathrm{A}$, mitoxantrone, and etoposide induced excessive toxicity and failed to achieve acceptable efficacy in phase I and II clinical trials [178]. Moreover, the use of statins in combination with other chemotherapeutic drugs improves neither progression-free survival nor overall survival [179]. Collectively, these results suggest that additional research is needed to confirm the safe and effective use of statins as an adjuvant in cancer therapy.

\section{Conclusions}

Here, we discussed the use of statins in different anti-cancer therapies. Statin alone has been used as an anti-proliferative and apoptotic action for in vitro studies in combination with other anti-cancer drugs for its synergistic action, or alone or in combination with other anti-cancer drugs for overcoming drug resistance induced by certain cancer therapies. Furthermore, we discussed the possibilities of inhibiting signaling pathways or signaling molecules by statins under different cancer therapies in different cancer cells. Statins show potential effects - either alone or in combination-on the basis of the type of cancer cells and gene mutation status. However, the use of statins as adjuvants, either alone or in combination, appears to benefit cancer patients in the context of drug repurposing to reduce the cost. 
Author Contributions: Writing—original draft preparation, N.T.P.; review and editing, C.-H.J. Both authors have read and agreed to the published version of the manuscript.

Funding: This research was supported by the Basic Science Research Program through the National Research Foundation of Korea (NRF) funded by the Ministry of Education [grant numbers NRF2016R1A6A1A03011325 and NRF-2018R1D1A3B07048623].

Institutional Review Board Statement: Not applicable.

Informed Consent Statement: Not applicable.

Data Availability Statement: No new data were created or analyzed in this study. Data sharing is not applicable to this article.

Conflicts of Interest: The authors declare no conflict of interest.

\section{References}

1. Torre, L.A.; Bray, F.; Siegel, R.L.; Ferlay, J.; Lortet-Tieulent, J.; Jemal, A. Global cancer statistics, 2012. CA Cancer J. Clin. 2015, 65, 87-108. [CrossRef] [PubMed]

2. Bray, F.; Ferlay, J.; Soerjomataram, I.; Siegel, R.L.; Torre, L.A.; Jemal, A. Global cancer statistics 2018: GLOBOCAN estimates of incidence and mortality worldwide for 36 cancers in 185 countries. CA Cancer J. Clin. 2018, 68, 394-424. [CrossRef] [PubMed]

3. Kartal-Yandim, M.; Adan-Gokbulut, A.; Baran, Y. Molecular mechanisms of drug resistance and its reversal in cancer. Crit. Rev. Biotechnol. 2016, 36, 716-726. [CrossRef]

4. Holohan, C.; van Schaeybroeck, S.; Longley, D.B.; Johnston, P.G. Cancer drug resistance: An evolving paradigm. Nat. Rev. Cancer 2013, 13, 714-726. [CrossRef]

5. Xie, Y.H.; Chen, Y.X.; Fang, J.Y. Comprehensive review of targeted therapy for colorectal cancer. Signal Transduct. Target. Ther. 2020, 5, 22. [CrossRef] [PubMed]

6. Sgouros, G.; Bodei, L.; McDevitt, M.R.; Nedrow, J.R. Radiopharmaceutical therapy in cancer: Clinical advances and challenges. Nat. Rev. Drug Discov. 2020, 19, 589-608. [CrossRef]

7. Stauss, H.J.; Tran, M.G.B. TCR Gene Therapy: Challenges, Opportunities, and Future Directions. Cells 2020, 9, 2567. [CrossRef]

8. Bondhopadhyay, B.; Sisodiya, S.; Chikara, A.; Khan, A.; Tanwar, P.; Afroze, D.; Singh, N.; Agrawal, U.; Mehrotra, R.; Hussain, S. Cancer immunotherapy: A promising dawn in cancer research. Am. J. Blood Res. 2020, 10, 375-385.

9. Batlle, E.; Clevers, H. Cancer stem cells revisited. Nat. Med. 2017, 23, 1124-1134. [CrossRef]

10. Paul, S.M.; Mytelka, D.S.; Dunwiddie, C.T.; Persinger, C.C.; Munos, B.H.; Lindborg, S.R.; Schacht, A.L. How to improve R\&D productivity: The pharmaceutical industry's grand challenge. Nat. Rev. Drug Discov. 2010, 9, 203-214. [CrossRef]

11. Moffat, J.G.; Rudolph, J.; Bailey, D. Phenotypic screening in cancer drug discovery-Past, present and future. Nat. Rev. Drug Discov. 2014, 13, 588-602. [CrossRef]

12. Petsko, G.A. When failure should be the option. BMC Biol. 2010, 8, 61. [CrossRef]

13. Umscheid, C.A.; Margolis, D.J.; Grossman, C.E. Key concepts of clinical trials: A narrative review. Postgrad. Med. 2011, 123, 194-204. [CrossRef] [PubMed]

14. Arrowsmith, J. Trial watch: Phase II failures: 2008-2010. Nat. Rev. Drug Discov. 2011, 10, 328-329. [CrossRef] [PubMed]

15. Langedijk, J.; Mantel-Teeuwisse, A.K.; Slijkerman, D.S.; Schutjens, M.H. Drug repositioning and repurposing: Terminology and definitions in literature. Drug Discov. Today 2015, 20, 1027-1034. [CrossRef]

16. Corsello, S.M.; Bittker, J.A.; Liu, Z.; Gould, J.; McCarren, P.; Hirschman, J.E.; Johnston, S.E.; Vrcic, A.; Wong, B.; Khan, M.; et al. The Drug Repurposing Hub: A next-generation drug library and information resource. Nat. Med. 2017, 23, 405-408. [CrossRef] [PubMed]

17. Zhang, Z.; Zhou, L.; Xie, N.; Nice, E.C.; Zhang, T.; Cui, Y.; Huang, C. Overcoming cancer therapeutic bottleneck by drug repurposing. Signal Transduct. Target. Ther. 2020, 5, 113. [CrossRef]

18. Gupta, S.C.; Sung, B.; Prasad, S.; Webb, L.J.; Aggarwal, B.B. Cancer drug discovery by repurposing: Teaching new tricks to old dogs. Trends Pharmacol. Sci. 2013, 34, 508-517. [CrossRef] [PubMed]

19. Pantziarka, P.; Bouche, G.; Meheus, L.; Sukhatme, V.; Sukhatme, V.P.; Vikas, P. The Repurposing Drugs in Oncology (ReDO) Project. Ecancermedicalscience 2014, 8, 442. [CrossRef]

20. Parvathaneni, V.; Kulkarni, N.S.; Muth, A.; Gupta, V. Drug repurposing: A promising tool to accelerate the drug discovery process. Drug Discov. Today 2019, 24, 2076-2085. [CrossRef]

21. Sleire, L.; Førde, H.E.; Netland, I.A.; Leiss, L.; Skeie, B.S.; Enger, P. Drug repurposing in cancer. Pharmacol. Res. 2017, 124, 74-91. [CrossRef] [PubMed]

22. Kelderman, S.; Schumacher, T.N.; Haanen, J.B. Acquired and intrinsic resistance in cancer immunotherapy. Mol. Oncol. 2014, 8 , 1132-1139. [CrossRef]

23. Dinić, J.; Efferth, T.; García-Sosa, A.T.; Grahovac, J.; Padrón, J.M.; Pajeva, I.; Rizzolio, F.; Saponara, S.; Spengler, G.; Tsakovska, I. Repurposing old drugs to fight multidrug resistant cancers. Drug Resist. Updates 2020, 52, 100713. [CrossRef] 
24. Tobert, J.A. Lovastatin and beyond: The history of the HMG-CoA reductase inhibitors. Nat. Rev. Drug Discov. 2003, 2, 517-526. [CrossRef] [PubMed]

25. Endo, A. A historical perspective on the discovery of statins. Proc. Jpn. Acad. Ser. B Phys. Biol. Sci. 2010, 86, 484-493. [CrossRef]

26. Manu, P.; Rogozea, L. The Discovery of Statins. Am. J. Ther. 2016, 23, e980-e981. [CrossRef] [PubMed]

27. Sirtori, C.R. The pharmacology of statins. Pharmacol. Res. 2014, 88, 3-11. [CrossRef] [PubMed]

28. Stossel, T.P. The discovery of statins. Cell 2008, 134, 903-905. [CrossRef]

29. Roth, B.D. The discovery and development of atorvastatin, a potent novel hypolipidemic agent. Prog. Med. Chem. 2002, 40, 1-22. [CrossRef]

30. van Leuven, S.I.; Kastelein, J.J. Atorvastatin. Expert Opin. Pharmacother. 2005, 6, 1191-1203. [CrossRef]

31. Garcia-Estevez, L.; Moreno-Bueno, G. Updating the role of obesity and cholesterol in breast cancer. Breast Cancer Res. 2019, $21,35$. [CrossRef] [PubMed]

32. Sharma, B.; Agnihotri, N. Role of cholesterol homeostasis and its efflux pathways in cancer progression. J. Steroid Biochem. Mol. Biol. 2019, 191, 105377. [CrossRef] [PubMed]

33. Wang, C.; Li, P.; Xuan, J.; Zhu, C.; Liu, J.; Shan, L.; Du, Q.; Ren, Y.; Ye, J. Cholesterol Enhances Colorectal Cancer Progression via ROS Elevation and MAPK Signaling Pathway Activation. Cell. Physiol. Biochem. 2017, 42, 729-742. [CrossRef] [PubMed]

34. Murai, T. Cholesterol lowering: Role in cancer prevention and treatment. Biol. Chem. 2015, 396, 1-11. [CrossRef]

35. Göbel, A.; Rauner, M.; Hofbauer, L.C.; Rachner, T.D. Cholesterol and beyond-The role of the mevalonate pathway in cancer biology. Biochim. Biophys. Acta Rev. Cancer 2020, 1873, 188351. [CrossRef]

36. Zhou, Y.; Yang, H.; Zhou, X.; Luo, H.; Tang, F.; Yang, J.; Alterovitz, G.; Cheng, L.; Ren, B. Lovastatin synergizes with itraconazole against planktonic cells and biofilms of Candida albicans through the regulation on ergosterol biosynthesis pathway. Appl. Microbiol. Biotechnol. 2018, 102, 5255-5264. [CrossRef]

37. Shojaei, S.; Alizadeh, J.; Thliveris, J.; Koleini, N.; Kardami, E.; Hatch, G.M.; Xu, F.; Hombach-Klonisch, S.; Klonisch, T.; Ghavami, S. Statins: A new approach to combat temozolomide chemoresistance in glioblastoma. J. Investig. Med. 2018, 66, 1083-1087. [CrossRef]

38. Braun, L.R.; Feldpausch, M.N.; Czerwonka, N.; Weiss, J.; Branch, K.; Lee, H.; Martinez-Salazar, E.L.; Torriani, M.; Sponseller, C.A.; Grinspoon, S.K.; et al. Effects of Pitavastatin on Insulin Sensitivity and Liver Fat: A Randomized Clinical Trial. J. Clin. Endocrinol. Metab. 2018, 103, 4176-4186. [CrossRef]

39. Ehmsen, S.; Pedersen, M.H.; Wang, G.; Terp, M.G.; Arslanagic, A.; Hood, B.L.; Conrads, T.P.; Leth-Larsen, R.; Ditzel, H.J. Increased Cholesterol Biosynthesis Is a Key Characteristic of Breast Cancer Stem Cells Influencing Patient Outcome. Cell Rep. 2019, 27, 3927.e6-3938.e6. [CrossRef]

40. Göbel, A.; Zinna, V.M.; Dell’Endice, S.; Jaschke, N.; Kuhlmann, J.D.; Wimberger, P.; Rachner, T.D. Anti-tumor effects of mevalonate pathway inhibition in ovarian cancer. BMC Cancer 2020, 20, 703. [CrossRef]

41. Calvillo-Argüelles, O.; Abdel-Qadir, H.; Michalowska, M.; Billia, F.; Suntheralingam, S.; Amir, E.; Thavendiranathan, P. Cardioprotective Effect of Statins in Patients With HER2-Positive Breast Cancer Receiving Trastuzumab Therapy. Can. J. Cardiol. 2019, 35, 153-159. [CrossRef]

42. Ricco, N.; Flor, A.; Wolfgeher, D.; Efimova, E.V.; Ramamurthy, A.; Appelbe, O.K.; Brinkman, J.; Truman, A.W.; Spiotto, M.T.; Kron, S.J. Mevalonate pathway activity as a determinant of radiation sensitivity in head and neck cancer. Mol. Oncol. 2019, 13, 1927-1943. [CrossRef]

43. Tan, X.L.; E., J.Y.; Lin, Y.; Rebbeck, T.R.; Lu, S.E.; Shang, M.; Kelly, W.K.; D’Amico, A.; Stein, M.N.; Zhang, L.; et al. Individual and joint effects of metformin and statins on mortality among patients with high-risk prostate cancer. Cancer Med. 2020, 9, 2379-2389. [CrossRef]

44. Hus, M.; Grzasko, N.; Szostek, M.; Pluta, A.; Helbig, G.; Woszczyk, D.; Adamczyk-Cioch, M.; Jawniak, D.; Legiec, W.; Morawska, M.; et al. Thalidomide, dexamethasone and lovastatin with autologous stem cell transplantation as a salvage immunomodulatory therapy in patients with relapsed and refractory multiple myeloma. Ann. Hematol. 2011, 90, 1161-1166. [CrossRef]

45. Kawata, S.; Yamasaki, E.; Nagase, T.; Inui, Y.; Ito, N.; Matsuda, Y.; Inada, M.; Tamura, S.; Noda, S.; Imai, Y.; et al. Effect of pravastatin on survival in patients with advanced hepatocellular carcinoma. A randomized controlled trial. Br. J. Cancer 2001, 84, 886-891. [CrossRef]

46. Schmidmaier, R.; Baumann, P.; Bumeder, I.; Meinhardt, G.; Straka, C.; Emmerich, B. First clinical experience with simvastatin to overcome drug resistance in refractory multiple myeloma. Eur. J. Haematol. 2007, 79, 240-243. [CrossRef]

47. Moon, D.C.; Lee, H.S.; Lee, Y.I.; Chung, M.J.; Park, J.Y.; Park, S.W.; Song, S.Y.; Chung, J.B.; Bang, S. Concomitant Statin Use Has a Favorable Effect on Gemcitabine-Erlotinib Combination Chemotherapy for Advanced Pancreatic Cancer. Yonsei Med. J. 2016, 57, 1124-1130. [CrossRef] [PubMed]

48. Baas, J.M.; Krens, L.L.; Tije, A.J.T.; Erdkamp, F.; van Wezel, T.; Morreau, H.; Gelderblom, H.; Guchelaar, H.J. Safety and efficacy of the addition of simvastatin to cetuximab in previously treated KRAS mutant metastatic colorectal cancer patients. Investig. New Drugs 2015, 33, 1242-1247. [CrossRef] [PubMed]

49. Konings, I.R.; van der Gaast, A.; van der Wijk, L.J.; de Jongh, F.E.; Eskens, F.A.; Sleijfer, S. The addition of pravastatin to chemotherapy in advanced gastric carcinoma: A randomised phase II trial. Eur. J. Cancer 2010, 46, 3200-3204. [CrossRef] [PubMed] 
50. Longo, J.; Hamilton, R.J.; Masoomian, M.; Khurram, N.; Branchard, E.; Mullen, P.J.; Elbaz, M.; Hersey, K.; Chadwick, D.; Ghai, S.; et al. A pilot window-of-opportunity study of preoperative fluvastatin in localized prostate cancer. Prostate Cancer Prostatic Dis. 2020, 23, 630-637. [CrossRef] [PubMed]

51. Knuuttila, E.; Riikonen, J.; Syvälä, H.; Auriola, S.; Murtola, T.J. Access and concentrations of atorvastatin in the prostate in men with prostate cancer. Prostate 2019, 79, 1412-1419. [CrossRef]

52. Goss, G.D.; Jonker, D.J.; Laurie, S.A.; Weberpals, J.I.; Oza, A.M.; Spaans, J.N.; La Porte, C.; Dimitroulakos, J. A phase I study of high-dose rosuvastatin with standard dose erlotinib in patients with advanced solid malignancies. J. Transl. Med. 2016, 14, 83. [CrossRef] [PubMed]

53. Nabati, M.; Janbabai, G.; Esmailian, J.; Yazdani, J. Effect of Rosuvastatin in Preventing Chemotherapy-Induced Cardiotoxicity in Women With Breast Cancer: A Randomized, Single-Blind, Placebo-Controlled Trial. J. Cardiovasc. Pharmacol. Ther. 2019, 24, 233-241. [CrossRef]

54. Sheikholeslami, K.; Ali Sher, A.; Lockman, S.; Kroft, D.; Ganjibakhsh, M.; Nejati-Koshki, K.; Shojaei, S.; Ghavami, S.; Rastegar, M. Simvastatin Induces Apoptosis in Medulloblastoma Brain Tumor Cells via Mevalonate Cascade Prenylation Substrates. Cancers 2019, 11, 994. [CrossRef] [PubMed]

55. Chang, H.L.; Chen, C.Y.; Hsu, Y.F.; Kuo, W.S.; Ou, G.; Chiu, P.T.; Huang, Y.H.; Hsu, M.J. Simvastatin induced HCT116 colorectal cancer cell apoptosis through p38MAPK-p53-survivin signaling cascade. Biochim. Biophys. Acta 2013, 1830, 4053-4064. [CrossRef] [PubMed]

56. Hwang, K.E.; Na, K.S.; Park, D.S.; Choi, K.H.; Kim, B.R.; Shim, H.; Jeong, E.T.; Kim, H.R. Apoptotic induction by simvastatin in human lung cancer A549 cells via Akt signaling dependent down-regulation of survivin. Investig. New Drugs 2011, 29, 945-952. [CrossRef]

57. Relja, B.; Meder, F.; Wilhelm, K.; Henrich, D.; Marzi, I.; Lehnert, M. Simvastatin inhibits cell growth and induces apoptosis and G0/G1 cell cycle arrest in hepatic cancer cells. Int. J. Mol. Med. 2010, 26, 735-741. [CrossRef]

58. Gallelli, L.; Falcone, D.; Scaramuzzino, M.; Pelaia, G.; D’Agostino, B.; Mesuraca, M.; Terracciano, R.; Spaziano, G.; Maselli, R.; Navarra, M.; et al. Effects of simvastatin on cell viability and proinflammatory pathways in lung adenocarcinoma cells exposed to hydrogen peroxide. BMC Pharmacol. Toxicol. 2014, 15, 67. [CrossRef] [PubMed]

59. Chen, M.C.; Tsai, Y.C.; Tseng, J.H.; Liou, J.J.; Horng, S.; Wen, H.C.; Fan, Y.C.; Zhong, W.B.; Hsu, S.P. Simvastatin Inhibits Cell Proliferation and Migration in Human Anaplastic Thyroid Cancer. Int. J. Mol. Sci. 2017, 18, 2690. [CrossRef]

60. Dongoran, R.A.; Wang, K.H.; Lin, T.J.; Yuan, T.C.; Liu, C.H. Anti-Proliferative Effect of Statins Is Mediated by DNMT1 Inhibition and p21 Expression in OSCC Cells. Cancers 2020, 12, 2084. [CrossRef]

61. Kodach, L.L.; Jacobs, R.J.; Voorneveld, P.W.; Wildenberg, M.E.; Verspaget, H.W.; van Wezel, T.; Morreau, H.; Hommes, D.W.; Peppelenbosch, M.P.; van den Brink, G.R.; et al. Statins augment the chemosensitivity of colorectal cancer cells inducing epigenetic reprogramming and reducing colorectal cancer cell 'stemness' via the bone morphogenetic protein pathway. Gut 2011, 60, 1544-1553. [CrossRef] [PubMed]

62. Zhou, Y.; Mi, M.T.; Zhu, J.D.; Zhang, Q.Y. Effects of lovastatin on proliferation and gap junctional intercellular communication of human breast cancer cell MCF-7. Ai Zheng Aizheng Chin. J. Cancer 2003, 22, 257-261.

63. Yang, T.; Yao, H.; He, G.; Song, L.; Liu, N.; Wang, Y.; Yang, Y.; Keller, E.T.; Deng, X. Effects of Lovastatin on MDA-MB-231 Breast Cancer Cells: An Antibody Microarray Analysis. J. Cancer 2016, 7, 192-199. [CrossRef]

64. Goc, A.; Kochuparambil, S.T.; Al-Husein, B.; Al-Azayzih, A.; Mohammad, S.; Somanath, P.R. Simultaneous modulation of the intrinsic and extrinsic pathways by simvastatin in mediating prostate cancer cell apoptosis. BMC Cancer 2012, 12, 409. [CrossRef] [PubMed]

65. Miller, T.; Yang, F.; Wise, C.E.; Meng, F.; Priester, S.; Munshi, M.K.; Guerrier, M.; Dostal, D.E.; Glaser, S.S. Simvastatin stimulates apoptosis in cholangiocarcinoma by inhibition of Rac1 activity. Dig. Liver Dis. 2011, 43, 395-403. [CrossRef]

66. Seeree, P.; Janvilisri, T.; Kangsamaksin, T.; Tohtong, R.; Kumkate, S. Downregulation of ABCA1 and ABCG1 transporters by simvastatin in cholangiocarcinoma cells. Oncol. Lett. 2019, 18, 5173-5184. [CrossRef] [PubMed]

67. Wang, C.; Li, T.; Yan, F.; Cai, W.; Zheng, J.; Jiang, X.; Sun, J. Effect of simvastatin and microRNA-21 inhibitor on metastasis and progression of human salivary adenoid cystic carcinoma. Biomed. Pharmacother. 2018, 105, 1054-1061. [CrossRef]

68. Chen, Y.A.; Lin, Y.J.; Lin, C.L.; Lin, H.J.; Wu, H.S.; Hsu, H.Y.; Sun, Y.C.; Wu, H.Y.; Lai, C.H.; Kao, C.H. Simvastatin Therapy for Drug Repositioning to Reduce the Risk of Prostate Cancer Mortality in Patients with Hyperlipidemia. Front. Pharmacol. 2018, 9 , 225. [CrossRef]

69. Jin, Y.; Xu, K.; Chen, Q.; Wang, B.; Pan, J.; Huang, S.; Wei, Y.; Ma, H. Simvastatin inhibits the development of radioresistant esophageal cancer cells by increasing the radiosensitivity and reversing EMT process via the PTEN-PI3K/AKT pathway. Exp. Cell Res. 2018, 362, 362-369. [CrossRef]

70. Trojan, P.J.; Bohatch-Junior, M.S.; Otuki, M.F.; Souza-Fonseca-Guimarães, F.; Svidnicki, P.V.; Nogaroto, V.; Fernandes, D.; Krum, E.A.; Favero, G.M. Pravastatin induces cell cycle arrest and decreased production of VEGF and bFGF in multiple myeloma cell line. Braz. J. Biol. 2016, 76, 59-65. [CrossRef]

71. Zhang, W.J.; Yang, S.H.; Tian, S.J.; Li, Z.X.; Gong, Y.X.; Qu, Y.; Mao, W.W. Effects of pravastatin on the proliferation and invasion of human hepatocarcinoma HepG2 cell line. Zhonghua Gan Zang Bing Za Zhi Zhonghua Ganzangbing Zazhi Chin. J. Hepatol. 2010, 18, 280-283. [CrossRef] 
72. Bourgier, C.; Auperin, A.; Rivera, S.; Boisselier, P.; Petit, B.; Lang, P.; Lassau, N.; Taourel, P.; Tetreau, R.; Azria, D.; et al. Pravastatin Reverses Established Radiation-Induced Cutaneous and Subcutaneous Fibrosis in Patients with Head and Neck Cancer: Results of the Biology-Driven Phase 2 Clinical Trial Pravacur. Int. J. Radiat. Oncol. Biol. Phys. 2019, 104, 365-373. [CrossRef] [PubMed]

73. Williams, A.B.; Li, L.; Nguyen, B.; Brown, P.; Levis, M.; Small, D. Fluvastatin inhibits FLT3 glycosylation in human and murine cells and prolongs survival of mice with FLT3/ITD leukemia. Blood 2012, 120, 3069-3079. [CrossRef] [PubMed]

74. Mück, A.O.; Seeger, H.; Wallwiener, D. Inhibitory effect of statins on the proliferation of human breast cancer cells. Int. J. Clin. Pharmacol. Ther. 2004, 42, 695-700. [CrossRef] [PubMed]

75. Crescencio, M.E.; Rodríguez, E.; Páez, A.; Masso, F.A.; Montaño, L.F.; López-Marure, R. Statins inhibit the proliferation and induce cell death of human papilloma virus positive and negative cervical cancer cells. Int. J. Biomed. Sci. 2009, 5, 411-420.

76. Sławińska-Brych, A.; Zdzisińska, B.; Kandefer-Szerszeń, M. Fluvastatin inhibits growth and alters the malignant phenotype of the C6 glioma cell line. Pharmacol. Rep. 2014, 66, 121-129. [CrossRef]

77. Kanugula, A.K.; Gollavilli, P.N.; Vasamsetti, S.B.; Karnewar, S.; Gopoju, R.; Ummanni, R.; Kotamraju, S. Statin-induced inhibition of breast cancer proliferation and invasion involves attenuation of iron transport: Intermediacy of nitric oxide and antioxidant defence mechanisms. FEBS J. 2014, 281, 3719-3738. [CrossRef]

78. Qi, X.F.; Zheng, L.; Lee, K.J.; Kim, D.H.; Kim, C.S.; Cai, D.Q.; Wu, Z.; Qin, J.W.; Yu, Y.H.; Kim, S.K. HMG-CoA reductase inhibitors induce apoptosis of lymphoma cells by promoting ROS generation and regulating Akt, Erk and p38 signals via suppression of mevalonate pathway. Cell Death Dis. 2013, 4, e518. [CrossRef]

79. Kanugula, A.K.; Dhople, V.M.; Völker, U.; Ummanni, R.; Kotamraju, S. Fluvastatin mediated breast cancer cell death: A proteomic approach to identify differentially regulated proteins in MDA-MB-231 cells. PLoS ONE 2014, 9, e108890. [CrossRef]

80. Jiang, P.; Mukthavaram, R.; Chao, Y.; Nomura, N.; Bharati, I.S.; Fogal, V.; Pastorino, S.; Teng, D.; Cong, X.; Pingle, S.C.; et al. In vitro and in vivo anticancer effects of mevalonate pathway modulation on human cancer cells. Br. J. Cancer 2014, 111, 1562-1571. [CrossRef]

81. Yang, Z.; Su, Z.; DeWitt, J.P.; Xie, L.; Chen, Y.; Li, X.; Han, L.; Li, D.; Xia, J.; Zhang, Y.; et al. Fluvastatin Prevents Lung Adenocarcinoma Bone Metastasis by Triggering Autophagy. EBioMedicine 2017, 19, 49-59. [CrossRef]

82. Al-Wahaibi, L.H.; Al-Saleem, M.S.M.; Ahmed, O.A.A.; Fahmy, U.A.; Alhakamy, N.A.; Eid, B.G.; Abdel-Naim, A.B.; Abdel-Mageed W.M.; AlRasheed, M.M.; Shazly, G.A. Optimized Conjugation of Fluvastatin to HIV-1 TAT Displays Enhanced Pro-Apoptotic Activity in HepG2 Cells. Int. J. Mol. Sci. 2020, 21, 4138. [CrossRef] [PubMed]

83. Ishikawa, T.; Hosaka, Y.Z.; Beckwitt, C.; Wells, A.; Oltvai, Z.N.; Warita, K. Concomitant attenuation of HMG-CoA reductase expression potentiates the cancer cell growth-inhibitory effect of statins and expands their efficacy in tumor cells with epithelial characteristics. Oncotarget 2018, 9, 29304-29315. [CrossRef] [PubMed]

84. Deezagi, A.; Safari, N. Rosuvastatin inhibit spheroid formation and epithelial-mesenchymal transition (EMT) in prostate cancer PC-3 cell line. Mol. Biol. Rep. 2020, 47, 8727-8737. [CrossRef] [PubMed]

85. Kumar, J.S.; Thirupataiah, B.; Medishetti, R.; Ray, A.; Bele, S.D.; Hossain, K.A.; Reddy, G.S.; Edwin, R.K.; Joseph, A.; Kumar, N.; et al. Rosuvastatin based novel 3-substituted isocoumarins/3-alkylidenephthalides: Ultrasound assisted synthesis and identification of new anticancer agents. Eur. J. Med. Chem. 2020, 201, 112335. [CrossRef] [PubMed]

86. Hosny, K.M.; Rizg, W.Y.; Khallaf, R.A. Preparation and Optimization of In Situ Gel Loaded with Rosuvastatin-Ellagic Acid Nanotransfersomes to Enhance the Anti-Proliferative Activity. Pharmaceutics 2020, 12, 263. [CrossRef]

87. Aldalaen, S.; El-Gogary, R.I.; Nasr, M. Fabrication of rosuvastatin-loaded polymeric nanocapsules: A promising modality for treating hepatic cancer delineated by apoptotic and cell cycle arrest assessment. Drug Dev. Ind. Pharm. 2019, 45, 55-62. [CrossRef]

88. Hamidreza Kheiri, M.; Alimohammadi, N.; Danafar, H. Preparation of biocompatible copolymeric micelles as a carrier of atorvastatin and rosuvastatin for potential anticancer activity study. Pharm. Dev. Technol. 2019, 24, 303-313. [CrossRef]

89. de Wolf, E.; Abdullah, M.I.; Jones, S.M.; Menezes, K.; Moss, D.M.; Drijfhout, F.P.; Hart, S.R.; Hoskins, C.; Stronach, E.A.; Richardson, A. Dietary geranylgeraniol can limit the activity of pitavastatin as a potential treatment for drug-resistant ovarian cancer. Sci. Rep. 2017, 7, 5410. [CrossRef]

90. Lee, N.; Tilija Pun, N.; Jang, W.J.; Bae, J.W.; Jeong, C.H. Pitavastatin induces apoptosis in oral squamous cell carcinoma through activation of FOXO3a. J. Cell Mol. Med. 2020, 24, 7055-7066. [CrossRef]

91. Efimova, E.V.; Ricco, N.; Labay, E.; Mauceri, H.J.; Flor, A.C.; Ramamurthy, A.; Sutton, H.G.; Weichselbaum, R.R.; Kron, S.J. HMG-CoA Reductase Inhibition Delays DNA Repair and Promotes Senescence after Tumor Irradiation. Mol. Cancer Ther. 2018, 17, 407-418. [CrossRef]

92. Denoyelle, C.; Albanese, P.; Uzan, G.; Hong, L.; Vannier, J.P.; Soria, J.; Soria, C. Molecular mechanism of the anti-cancer activity of cerivastatin, an inhibitor of HMG-CoA reductase, on aggressive human breast cancer cells. Cell. Signal. 2003, 15, 327-338. [CrossRef]

93. Obara, S.; Nakata, M.; Takeshima, H.; Kuratsu, J.; Maruyama, I.; Kitajima, I. Inhibition of migration of human glioblastoma cells by cerivastatin in association with focal adhesion kinase (FAK). Cancer Lett. 2002, 185, 153-161. [CrossRef]

94. Denoyelle, C.; Vasse, M.; Körner, M.; Mishal, Z.; Ganné, F.; Vannier, J.P.; Soria, J.; Soria, C. Cerivastatin, an inhibitor of HMG-CoA reductase, inhibits the signaling pathways involved in the invasiveness and metastatic properties of highly invasive breast cancer cell lines: An in vitro study. Carcinogenesis 2001, 22, 1139-1148. [CrossRef] [PubMed]

95. Wong, W.W.; Tan, M.M.; Xia, Z.; Dimitroulakos, J.; Minden, M.D.; Penn, L.Z. Cerivastatin triggers tumor-specific apoptosis with higher efficacy than lovastatin. Clin. Cancer Res. 2001, 7, 2067-2075. [PubMed] 
96. Vincent, L.; Chen, W.; Hong, L.; Mirshahi, F.; Mishal, Z.; Mirshahi-Khorassani, T.; Vannier, J.P.; Soria, J.; Soria, C. Inhibition of endothelial cell migration by cerivastatin, an HMG-CoA reductase inhibitor: Contribution to its anti-angiogenic effect. FEBS Lett. 2001, 495, 159-166. [CrossRef]

97. Rivankar, S. An overview of doxorubicin formulations in cancer therapy. J. Cancer Res. Ther. 2014, 10, 853-858. [CrossRef] [PubMed]

98. Mallappa, S.; Neeli, P.K.; Karnewar, S.; Kotamraju, S. Doxorubicin induces prostate cancer drug resistance by upregulation of ABCG4 through GSH depletion and CREB activation: Relevance of statins in chemosensitization. Mol. Carcinog. 2019, 58, 1118-1133. [CrossRef] [PubMed]

99. Yu, J.S.; Shin, D.H.; Kim, J.S. Repurposing of Fluvastatin as an Anticancer Agent against Breast Cancer Stem Cells via Encapsulation in a Hyaluronan-Conjugated Liposome. Pharmaceutics 2020, 12, 1133. [CrossRef] [PubMed]

100. Fromigué, O.; Hamidouche, Z.; Marie, P.J. Statin-induced inhibition of 3-hydroxy-3-methyl glutaryl coenzyme a reductase sensitizes human osteosarcoma cells to anticancer drugs. J. Pharmacol. Exp. Ther. 2008, 325, 595-600. [CrossRef]

101. Kozar, K.; Kaminski, R.; Legat, M.; Kopec, M.; Nowis, D.; Skierski, J.S.; Koronkiewicz, M.; Jakóbisiak, M.; Golab, J. Cerivastatin demonstrates enhanced antitumor activity against human breast cancer cell lines when used in combination with doxorubicin or cisplatin. Int. J. Oncol. 2004, 24, 1149-1157. [CrossRef] [PubMed]

102. Riganti, C.; Orecchia, S.; Pescarmona, G.; Betta, P.G.; Ghigo, D.; Bosia, A. Statins revert doxorubicin resistance via nitric oxide in malignant mesothelioma. Int. J. Cancer 2006, 119, 17-27. [CrossRef]

103. Środa-Pomianek, K.; Michalak, K.; Palko-Łabuz, A.; Uryga, A.; Świątek, P.; Majkowski, M.; Wesołowska, O. The Combined Use of Phenothiazines and Statins Strongly Affects Doxorubicin-Resistance, Apoptosis, and Cox-2 Activity in Colon Cancer Cells. Int. J. Mol. Sci. 2019, 20, 955. [CrossRef]

104. Zhang, X.H.; Zhang, R.; Zhu, Z.L.; Xu, S.N.; Li, Y.F. Effects of Simvastatin on Expression of Multidrug Resistance Gene and Protein of SHI-1 Cells. Zhongguo Shi Yan Xue Ye Xue Za Zhi 2016, 24, 1659-1664. [CrossRef] [PubMed]

105. Rigoni, M.; Riganti, C.; Vitale, C.; Griggio, V.; Campia, I.; Robino, M.; Foglietta, M.; Castella, B.; Sciancalepore, P.; Buondonno, I.; et al. Simvastatin and downstream inhibitors circumvent constitutive and stromal cell-induced resistance to doxorubicin in IGHV unmutated CLL cells. Oncotarget 2015, 6, 29833-29846. [CrossRef] [PubMed]

106. Greife, A.; Tukova, J.; Steinhoff, C.; Scott, S.D.; Schulz, W.A.; Hatina, J. Establishment and characterization of a bladder cancer cell line with enhanced doxorubicin resistance by mevalonate pathway activation. Tumour Biol. 2015, 36, 3293-3300. [CrossRef]

107. Środa-Pomianek, K.; Michalak, K.; Palko-Łabuz, A.; Uryga, A.; Szczęśniak-Sięga, B.; Wesołowska, O. Simvastatin Strongly Augments Proapoptotic, Anti-inflammatory and Cytotoxic Activity of Oxicam Derivatives in Doxorubicin-resistant Colon Cancer Cells. Anticancer Res. 2019, 39, 727-734. [CrossRef]

108. Palko-Łabuz, A.; Środa-Pomianek, K.; Wesołowska, O.; Kostrzewa-Susłow, E.; Uryga, A.; Michalak, K. MDR reversal and pro-apoptotic effects of statins and statins combined with flavonoids in colon cancer cells. Biomed. Pharmacother. 2019, 109, 1511-1522. [CrossRef]

109. Ahn, K.S.; Sethi, G.; Aggarwal, B.B. Reversal of chemoresistance and enhancement of apoptosis by statins through downregulation of the NF-kappaB pathway. Biochem. Pharmacol. 2008, 75, 907-913. [CrossRef]

110. Oku, Y.; Nishiya, N.; Shito, T.; Yamamoto, R.; Yamamoto, Y.; Oyama, C.; Uehara, Y. Small molecules inhibiting the nuclear localization of YAP/TAZ for chemotherapeutics and chemosensitizers against breast cancers. FEBS Open Bio 2015, 5, 542-549. [CrossRef] [PubMed]

111. Henslee, A.B.; Steele, T.A. Combination statin and chemotherapy inhibits proliferation and cytotoxicity of an aggressive natural killer cell leukemia. Biomark. Res. 2018, 6, 26. [CrossRef] [PubMed]

112. Álvarez, P.; Marchal, J.A.; Boulaiz, H.; Carrillo, E.; Vélez, C.; Rodríguez-Serrano, F.; Melguizo, C.; Prados, J.; Madeddu, R.; Aranega, A. 5-Fluorouracil derivatives: A patent review. Expert Opin. Ther. Pat. 2012, 22, 107-123. [CrossRef] [PubMed]

113. Takimoto, C.H.; Yee, L.K.; Venzon, D.J.; Schuler, B.; Grollman, F.; Chabuk, C.; Hamilton, J.M.; Chen, A.P.; Allegra, C.J.; Grem, J.L. High inter- and intrapatient variation in 5-fluorouracil plasma concentrations during a prolonged drug infusion. Clin. Cancer Res. 1999, 5, 1347-1352. [PubMed]

114. Peters, G.J.; Lankelma, J.; Kok, R.M.; Noordhuis, P.; van Groeningen, C.J.; van der Wilt, C.L.; Meyer, S.; Pinedo, H.M. Prolonged retention of high concentrations of 5-fluorouracil in human and murine tumors as compared with plasma. Cancer Chemother. Pharmacol. 1993, 31, 269-276. [CrossRef] [PubMed]

115. Wang, W.; Collie-Duguid, E.; Cassidy, J. Cerivastatin enhances the cytotoxicity of 5-fluorouracil on chemosensitive and resistant colorectal cancer cell lines. FEBS Lett. 2002, 531, 415-420. [CrossRef]

116. Luput, L.; Sesarman, A.; Porfire, A.; Achim, M.; Muntean, D.; Casian, T.; Patras, L.; Rauca, V.F.; Drotar, D.M.; Stejerean, I.; et al. Liposomal simvastatin sensitizes C26 murine colon carcinoma to the antitumor effects of liposomal 5-fluorouracil in vivo. Cancer Sci. 2020, 111, 1344-1356. [CrossRef]

117. Manu, K.A.; Shanmugam, M.K.; Li, F.; Chen, L.; Siveen, K.S.; Ahn, K.S.; Kumar, A.P.; Sethi, G. Simvastatin sensitizes human gastric cancer xenograft in nude mice to capecitabine by suppressing nuclear factor-kappa B-regulated gene products. J. Mol. Med. 2014, 92, 267-276. [CrossRef]

118. Wilhelm, S.M.; Adnane, L.; Newell, P.; Villanueva, A.; Llovet, J.M.; Lynch, M. Preclinical overview of sorafenib, a multikinase inhibitor that targets both Raf and VEGF and PDGF receptor tyrosine kinase signaling. Mol. Cancer Ther. 2008, 7, 3129-3140. [CrossRef] 
119. Zhang, S.; Doudican, N.A.; Quay, E.; Orlow, S.J. Fluvastatin enhances sorafenib cytotoxicity in melanoma cells via modulation of AKT and JNK signaling pathways. Anticancer Res. 2011, 31, 3259-3265.

120. Zhou, T.Y.; Zhuang, L.H.; Hu, Y.; Zhou, Y.L.; Lin, W.K.; Wang, D.D.; Wan, Z.Q.; Chang, L.L.; Chen, Y.; Ying, M.D.; et al. Inactivation of hypoxia-induced YAP by statins overcomes hypoxic resistance tosorafenib in hepatocellular carcinoma cells. Sci. Rep. 2016, 6, 30483. [CrossRef]

121. Cheng, Y.; Luo, R.; Zheng, H.; Wang, B.; Liu, Y.; Liu, D.; Chen, J.; Xu, W.; Li, A.; Zhu, Y. Synergistic anti-tumor efficacy of sorafenib and fluvastatin in hepatocellular carcinoma. Oncotarget 2017, 8, 23265-23276. [CrossRef] [PubMed]

122. Feng, J.; Dai, W.; Mao, Y.; Wu, L.; Li, J.; Chen, K.; Yu, Q.; Kong, R.; Li, S.; Zhang, J.; et al. Simvastatin re-sensitizes hepatocellular carcinoma cells to sorafenib by inhibiting HIF-1 $\alpha /$ PPAR- $\gamma /$ PKM2-mediated glycolysis. J. Exp. Clin. Cancer Res. 2020, 39, 24. [CrossRef] [PubMed]

123. Riaño, I.; Martín, L.; Varela, M.; Serrano, T.; Núñez, O.; Mínguez, B.; Rodrigues, P.M.; Perugorria, M.J.; Banales, J.M.; Arenas, J.I. Efficacy and Safety of the Combination of Pravastatin and Sorafenib for the Treatment of Advanced Hepatocellular Carcinoma (ESTAHEP Clinical Trial). Cancers 2020, 12, 1900. [CrossRef] [PubMed]

124. Rich, J.N.; Reardon, D.A.; Peery, T.; Dowell, J.M.; Quinn, J.A.; Penne, K.L.; Wikstrand, C.J.; van Duyn, L.B.; Dancey, J.E.; McLendon, R.E.; et al. Phase II trial of gefitinib in recurrent glioblastoma. J. Clin. Oncol. 2004, 22, 133-142. [CrossRef]

125. Barber, T.D.; Vogelstein, B.; Kinzler, K.W.; Velculescu, V.E. Somatic mutations of EGFR in colorectal cancers and glioblastomas. N. Engl. J. Med. 2004, 351, 2883. [CrossRef] [PubMed]

126. Cemeus, C.; Zhao, T.T.; Barrett, G.M.; Lorimer, I.A.; Dimitroulakos, J. Lovastatin enhances gefitinib activity in glioblastoma cells irrespective of EGFRvIII and PTEN status. J. Neurooncol. 2008, 90, 9-17. [CrossRef]

127. Yang, S.H.; Lin, H.Y.; Chang, V.H.; Chen, C.C.; Liu, Y.R.; Wang, J.; Zhang, K.; Jiang, X.; Yen, Y. Lovastatin overcomes gefitinib resistance through TNF- $\alpha$ signaling in human cholangiocarcinomas with different LKB1 statuses in vitro and in vivo. Oncotarget 2015, 6, 23857-23873. [CrossRef]

128. Eberhard, D.A.; Johnson, B.E.; Amler, L.C.; Goddard, A.D.; Heldens, S.L.; Herbst, R.S.; Ince, W.L.; Jänne, P.A.; Januario, T.; Johnson, D.H.; et al. Mutations in the epidermal growth factor receptor and in KRAS are predictive and prognostic indicators in patients with non-small-cell lung cancer treated with chemotherapy alone and in combination with erlotinib. J. Clin. Oncol. 2005, 23, 5900-5909. [CrossRef]

129. Park, I.H.; Kim, J.Y.; Jung, J.I.; Han, J.Y. Lovastatin overcomes gefitinib resistance in human non-small cell lung cancer cells with K-Ras mutations. Investig. New Drugs 2010, 28, 791-799. [CrossRef]

130. Hwang, K.E.; Kwon, S.J.; Kim, Y.S.; Park, D.S.; Kim, B.R.; Yoon, K.H.; Jeong, E.T.; Kim, H.R. Effect of simvastatin on the resistance to EGFR tyrosine kinase inhibitors in a non-small cell lung cancer with the T790M mutation of EGFR. Exp. Cell Res. 2014, 323, 288-296. [CrossRef]

131. Lee, H.Y.; Kim, I.K.; Lee, H.I.; Mo, J.Y.; Yeo, C.D.; Kang, H.H.; Moon, H.S.; Lee, S.H. The apoptotic effect of simvastatin via the upregulation of BIM in nonsmall cell lung cancer cells. Exp. Lung Res. 2016, 42, 14-23. [CrossRef] [PubMed]

132. Chen, J.; Bi, H.; Hou, J.; Zhang, X.; Zhang, C.; Yue, L.; Wen, X.; Liu, D.; Shi, H.; Yuan, J.; et al. Atorvastatin overcomes gefitinib resistance in KRAS mutant human non-small cell lung carcinoma cells. Cell Death Dis. 2013, 4, e814. [CrossRef] [PubMed]

133. Otahal, A.; Aydemir, D.; Tomasich, E.; Minichsdorfer, C. Delineation of cell death mechanisms induced by synergistic effects of statins and erlotinib in non-small cell lung cancer cell (NSCLC) lines. Sci. Rep. 2020, 10, 959. [CrossRef] [PubMed]

134. Glodkowska-Mrowka, E.; Mrowka, P.; Basak, G.W.; Niesiobedzka-Krezel, J.; Seferynska, I.; Wlodarski, P.K.; Jakobisiak, M.; Stoklosa, T. Statins inhibit ABCB1 and ABCG2 drug transporter activity in chronic myeloid leukemia cells and potentiate antileukemic effects of imatinib. Exp. Hematol. 2014, 42, 439-447. [CrossRef]

135. Oh, B.; Kim, T.Y.; Min, H.J.; Kim, M.; Kang, M.S.; Huh, J.Y.; Kim, Y.; Lee, D.S. Synergistic killing effect of imatinib and simvastatin on imatinib-resistant chronic myelogenous leukemia cells. Anticancer Drugs 2013, 24, 20-31. [CrossRef]

136. Dasari, S.; Tchounwou, P.B. Cisplatin in cancer therapy: Molecular mechanisms of action. Eur. J. Pharmacol. 2014, 740, 364-378. [CrossRef]

137. Zhang, Y.; Liu, Y.; Duan, J.; Wang, H.; Zhang, Y.; Qiao, K.; Wang, J. Cholesterol depletion sensitizes gallbladder cancer to cisplatin by impairing DNA damage response. Cell Cycle 2019, 18, 3337-3350. [CrossRef]

138. Koi, C.; Izumi, H.; Kurita, T.; Nguyen, T.T.; Murakami, M.; Yoshiura, Y.; Hachisuga, T.; Morimoto, Y. Lovastatin induced Kruppel like factor 2 (KLF2), Kruppel like factor 6 (KLF6) and Ras homolog family member B (RHOB) genes and preferentially led to viability reduction of Cisplatin-resistant cells. Oncotarget 2017, 8, 106429-106442. [CrossRef]

139. Hu, T.; Shen, H.; Huang, H.; Yang, Z.; Zhou, Y.; Zhao, G. Cholesterol-lowering drug pitavastatin targets lung cancer and angiogenesis via suppressing prenylation-dependent Ras/Raf/MEK and PI3K/Akt/mTOR signaling. Anticancer Drugs 2020, 31, 377-384. [CrossRef]

140. Plunkett, W.; Huang, P.; Xu, Y.Z.; Heinemann, V.; Grunewald, R.; Gandhi, V. Gemcitabine: Metabolism, mechanisms of action, and self-potentiation. Semin. Oncol. 1995, 22, 3-10.

141. Kawashiri, T.; Tokunaga, A.; Kobayashi, D.; Shimazoe, T. Anti-tumor Activities of 3-Hydroxy-3-methylglutaryl Coenzyme A (HMG-CoA) Reductase Inhibitors and Bisphosphonates in Pancreatic Cell Lines Which Show Poor Responses to Gemcitabine. Biol. Pharm. Bull. 2020, 43, 49-52. [CrossRef] 
142. Kitagawa, K.; Moriya, K.; Kaji, K.; Saikawa, S.; Sato, S.; Nishimura, N.; Namisaki, T.; Akahane, T.; Mitoro, A.; Yoshiji, H. Atorvastatin Augments Gemcitabine-Mediated Anti-Cancer Effects by Inhibiting Yes-Associated Protein in Human Cholangiocarcinoma Cells. Int. J. Mol. Sci. 2020, 21, 7588. [CrossRef]

143. Chen, Y.H.; Chen, Y.C.; Lin, C.C.; Hsieh, Y.P.; Hsu, C.S.; Hsieh, M.C. Synergistic Anticancer Effects of Gemcitabine with Pitavastatin on Pancreatic Cancer Cell Line MIA PaCa-2 in vitro and in vivo. Cancer Manag. Res. 2020, 12, 4645-4665. [CrossRef] [PubMed]

144. Xian, G.; Zhao, J.; Qin, C.; Zhang, Z.; Lin, Y.; Su, Z. Simvastatin attenuates macrophage-mediated gemcitabine resistance of pancreatic ductal adenocarcinoma by regulating the TGF- $\beta 1 /$ Gfi-1 axis. Cancer Lett. 2017, 385, 65-74. [CrossRef] [PubMed]

145. Sharma, A.; Shah, S.R.; Illum, H.; Dowell, J. Vemurafenib: Targeted inhibition of mutated BRAF for treatment of advanced melanoma and its potential in other malignancies. Drugs 2012, 72, 2207-2222. [CrossRef]

146. Held, M.A.; Langdon, C.G.; Platt, J.T.; Graham-Steed, T.; Liu, Z.; Chakraborty, A.; Bacchiocchi, A.; Koo, A.; Haskins, J.W.; Bosenberg, M.W.; et al. Genotype-selective combination therapies for melanoma identified by high-throughput drug screening. Cancer Discov. 2013, 3, 52-67. [CrossRef] [PubMed]

147. Theodosakis, N.; Langdon, C.G.; Micevic, G.; Krykbaeva, I.; Means, R.E.; Stern, D.F.; Bosenberg, M.W. Inhibition of isoprenylation synergizes with MAPK blockade to prevent growth in treatment-resistant melanoma, colorectal, and lung cancer. Pigment. Cell Melanoma Res. 2019, 32, 292-302. [CrossRef]

148. Nishiya, M.; Yasuhira, S.; Shibazaki, M.; Oikawa, H.; Masuda, T.; Maesawa, C. Fluvastatin exerts an antitumor effect in vemurafenib-resistant melanoma cells. Anticancer Drugs 2019, 30, 451-457. [CrossRef]

149. Liu, Y.; Chen, L.; Gong, Z.; Shen, L.; Kao, C.; Hock, J.M.; Sun, L.; Li, X. Lovastatin enhances adenovirus-mediated TRAIL induced apoptosis by depleting cholesterol of lipid rafts and affecting CAR and death receptor expression of prostate cancer cells. Oncotarget 2015, 6, 3055-3070. [CrossRef] [PubMed]

150. Iizuka-Ohashi, M.; Watanabe, M.; Sukeno, M.; Morita, M.; Hoang, N.T.H.; Kuchimaru, T.; Kizaka-Kondoh, S.; Sowa, Y.; Sakaguchi, K.; Taguchi, T.; et al. Blockage of the mevalonate pathway overcomes the apoptotic resistance to MEK inhibitors with suppressing the activation of Akt in cancer cells. Oncotarget 2018, 9, 19597-19612. [CrossRef]

151. Abdullah, M.I.; Abed, M.N.; Khanim, F.; Richardson, A. Screening a library of approved drugs reveals that prednisolone synergizes with pitavastatin to induce ovarian cancer cell death. Sci. Rep. 2019, 9, 9632. [CrossRef]

152. Zhu, Z.; Zhang, P.; Li, N.; Kiang, K.M.Y.; Cheng, S.Y.; Wong, V.K.; Leung, G.K. Lovastatin Enhances Cytotoxicity of Temozolomide via Impairing Autophagic Flux in Glioblastoma Cells. Biomed Res. Int. 2019, 2019, 2710693. [CrossRef] [PubMed]

153. Zhong, W.B.; Tsai, Y.C.; Chin, L.H.; Tseng, J.H.; Tang, L.W.; Horng, S.; Fan, Y.C.; Hsu, S.P. A Synergistic Anti-Cancer Effect of Troglitazone and Lovastatin in a Human Anaplastic Thyroid Cancer Cell Line and in a Mouse Xenograft Model. Int. J. Mol. Sci. 2018, 19, 1834. [CrossRef] [PubMed]

154. Tsubaki, M.; Takeda, T.; Obata, N.; Kawashima, K.; Tabata, M.; Imano, M.; Satou, T.; Nishida, S. Combination therapy with dacarbazine and statins improved the survival rate in mice with metastatic melanoma. J. Cell. Physiol. 2019, 234, 17975-17989. [CrossRef] [PubMed]

155. Castellanos-Esparza, Y.C.; Wu, S.; Huang, L.; Buquet, C.; Shen, R.; Sanchez-Gonzalez, B.; García Latorre, E.A.; Boyer, O.; Varin, R.; Jiménez-Zamudio, L.A.; et al. Synergistic promoting effects of pentoxifylline and simvastatin on the apoptosis of triple-negative MDA-MB-231 breast cancer cells. Int. J. Oncol. 2018, 52, 1246-1254. [CrossRef]

156. Ingersoll, M.A.; Miller, D.R.; Martinez, O.; Wakefield, C.B.; Hsieh, K.C.; Simha, M.V.; Kao, C.L.; Chen, H.T.; Batra, S.K.; Lin, M.F. Statin derivatives as therapeutic agents for castration-resistant prostate cancer. Cancer Lett. 2016, 383, 94-105. [CrossRef] [PubMed]

157. Lee, J.S.; Roberts, A.; Juarez, D.; Vo, T.T.; Bhatt, S.; Herzog, L.O.; Mallya, S.; Bellin, R.J.; Agarwal, S.K.; Salem, A.H.; et al. Statins enhance efficacy of venetoclax in blood cancers. Sci. Transl. Med. 2018, 10, eaaq1240. [CrossRef]

158. Rauca, V.F.; Licarete, E.; Luput, L.; Sesarman, A.; Patras, L.; Bulzu, P.; Rakosy-Tican, E.; Banciu, M. Combination therapy of simvastatin and 5, 6-dimethylxanthenone-4-acetic acid synergistically suppresses the aggressiveness of B16.F10 melanoma cells. PLoS ONE 2018, 13, e0202827. [CrossRef]

159. Sethunath, V.; Hu, H.; de Angelis, C.; Veeraraghavan, J.; Qin, L.; Wang, N.; Simon, L.M.; Wang, T.; Fu, X.; Nardone, A.; et al. Targeting the Mevalonate Pathway to Overcome Acquired Anti-HER2 Treatment Resistance in Breast Cancer. Mol. Cancer Res. 2019, 17, 2318-2330. [CrossRef]

160. Iannelli, F.; Roca, M.S.; Lombardi, R.; Ciardiello, C.; Grumetti, L.; de Rienzo, S.; Moccia, T.; Vitagliano, C.; Sorice, A.; Costantini, S.; et al. Synergistic antitumor interaction of valproic acid and simvastatin sensitizes prostate cancer to docetaxel by targeting CSCs compartment via YAP inhibition. J. Exp. Clin. Cancer Res. 2020, 39, 213. [CrossRef]

161. Ghasemi, M.; Malek, M.; Javanmard, S.H.; Ghasemi, A.; Esfahani, H.N.; Vaseghi, G. Atorvastatin enhances apoptotic effects of tamoxifen on melanoma cancer cells. Bratisl. Lek. Listy 2019, 120, 752-756. [CrossRef] [PubMed]

162. Xiao, H.; Zhang, Q.; Lin, Y.; Reddy, B.S.; Yang, C.S. Combination of atorvastatin and celecoxib synergistically induces cell cycle arrest and apoptosis in colon cancer cells. Int. J. Cancer 2008, 122, 2115-2124. [CrossRef]

163. Goda, A.E.; Elsisi, A.E.; Sokkar, S.S.; Abdelrazik, N.M. Enhanced in vivo targeting of estrogen receptor alpha signaling in murine mammary adenocarcinoma by nilotinib/rosuvastatin novel combination. Toxicol. Appl. Pharmacol. 2020, 404, 115185. [CrossRef]

164. El Sayed, I.; Helmy, M.W.; El-Abhar, H.S. Inhibition of SRC/FAK cue: A novel pathway for the synergistic effect of rosuvastatin on the anti-cancer effect of dasatinib in hepatocellular carcinoma. Life Sci. 2018, 213, 248-257. [CrossRef] [PubMed] 
165. Boulate, G.; Amazit, L.; Naman, A.; Seck, A.; Paci, A.; Lombes, A.; Pussard, E.; Baudin, E.; Lombes, M.; Hescot, S. Potentiation of mitotane action by rosuvastatin: New insights for adrenocortical carcinoma management. Int. J. Oncol. 2019, 54, $2149-2156$. [CrossRef]

166. Al-Qatati, A.; Aliwaini, S. Combined pitavastatin and dacarbazine treatment activates apoptosis and autophagy resulting in synergistic cytotoxicity in melanoma cells. Oncol. Lett. 2017, 14, 7993-7999. [CrossRef] [PubMed]

167. Kobayashi, M.; Gouda, K.; Chisaki, I.; Asada, K.; Ogura, J.; Takahashi, N.; Konishi, T.; Koshida, Y.; Sasaki, S.; Yamaguchi, H.; et al. Regulation of multidrug resistance protein 2 (MRP2, ABCC2) expression by statins: Involvement of SREBP-mediated gene regulation. Int. J. Pharm. 2013, 452, 36-41. [CrossRef] [PubMed]

168. Delang, L.; Scheers, E.; Grabner, M.; Verpaalen, B.; Helsen, N.; Vanstreels, E.; Daelemans, D.; Verfaillie, C.; Neyts, J. Understanding the molecular mechanism of host-based statin resistance in hepatitis $C$ virus replicon containing cells. Biochem. Pharmacol. 2015, 96, 190-201. [CrossRef] [PubMed]

169. Masko, E.M.; Alfaqih, M.A.; Solomon, K.R.; Barry, W.T.; Newgard, C.B.; Muehlbauer, M.J.; Valilis, N.A.; Phillips, T.E.; Poulton, S.H.; Freedland, A.R.; et al. Evidence for Feedback Regulation Following Cholesterol Lowering Therapy in a Prostate Cancer Xenograft Model. Prostate 2017, 77, 446-457. [CrossRef] [PubMed]

170. Lettiero, B.; Inasu, M.; Kimbung, S.; Borgquist, S. Insensitivity to atorvastatin is associated with increased accumulation of intracellular lipid droplets and fatty acid metabolism in breast cancer cells. Sci. Rep. 2018, 8, 5462. [CrossRef]

171. Göbel, A.; Breining, D.; Rauner, M.; Hofbauer, L.C.; Rachner, T.D. Induction of 3-hydroxy-3-methylglutaryl-CoA reductase mediates statin resistance in breast cancer cells. Cell Death Dis. 2019, 10, 91. [CrossRef]

172. El-Ashmawy, N.E.; Al-Ashmawy, G.M.; Amr, E.A.; Khedr, E.G. Inhibition of lovastatin- and docosahexaenoic acid-initiated autophagy in triple negative breast cancer reverted resistance and enhanced cytotoxicity. Life Sci. 2020, 259, 118212. [CrossRef]

173. Reiner, Z. Resistance and intolerance to statins. Nutr. Metab. Cardiovasc. Dis. 2014, 24, 1057-1066. [CrossRef] [PubMed]

174. Cauley, J.A.; McTiernan, A.; Rodabough, R.J.; LaCroix, A.; Bauer, D.C.; Margolis, K.L.; Paskett, E.D.; Vitolins, M.Z.; Furberg, C.D.; Chlebowski, R.T. Statin use and breast cancer: Prospective results from the Women's Health Initiative. J. Natl. Cancer Inst. 2006, 98, 700-707. [CrossRef]

175. Simon, T.G.; Bonilla, H.; Yan, P.; Chung, R.T.; Butt, A.A. Atorvastatin and fluvastatin are associated with dose-dependent reductions in cirrhosis and hepatocellular carcinoma, among patients with hepatitis $C$ virus: Results from ERCHIVES. Hepatology 2016, 64, 47-57. [CrossRef] [PubMed]

176. McKay, R.R.; Lin, X.; Albiges, L.; Fay, A.P.; Kaymakcalan, M.D.; Mickey, S.S.; Ghoroghchian, P.P.; Bhatt, R.S.; Kaffenberger, S.D.; Simantov, R.; et al. Statins and survival outcomes in patients with metastatic renal cell carcinoma. Eur. J. Cancer 2016, 52, 155-162. [CrossRef] [PubMed]

177. Hung, M.S.; Chen, I.C.; Lee, C.P.; Huang, R.J.; Chen, P.C.; Tsai, Y.H.; Yang, Y.H. Statin improves survival in patients with EGFR-TKI lung cancer: A nationwide population-based study. PLoS ONE 2017, 12, e0171137. [CrossRef]

178. Chen, T.L.; Estey, E.H.; Othus, M.; Gardner, K.M.; Markle, L.J.; Walter, R.B. Cyclosporine modulation of multidrug resistance in combination with pravastatin, mitoxantrone and etoposide for adult patients with relapsed/refractory acute myeloid leukemia: A phase 1/2 study. Leuk. Lymphoma 2013, 54, 2534-2536. [CrossRef]

179. Farooqi, M.A.M.; Malhotra, N.; Mukherjee, S.D.; Sanger, S.; Dhesy-Thind, S.K.; Ellis, P.; Leong, D.P. Statin therapy in the treatment of active cancer: A systematic review and meta-analysis of randomized controlled trials. PLoS ONE 2018, 13, e0209486. [CrossRef] 